\title{
BIBLIOGRÁFIA
}

\section{A magyar nyomda-, könyv-, sajtó- és könyvtártörténeti szakirodalom $2016^{*}$-ban}

\section{Röviditések:}

$\begin{array}{ll}\text { GeodKart } & =\text { Geodézia és Kartográfia } \\ \text { ItK } & =\text { Irodalomtörténeti Közlemények } \\ \text { KEK } & =\text { Közép-Európai Közlemények } \\ \text { KF } & =\text { Könyvtári Figyelő } \\ \text { KKK } & =\text { Könyv, Könyvtár, Könyvtáros } \\ \text { KN } & =\text { Könyv és Nevelés } \\ \text { MG } & =\text { Magyar Grafika } \\ \text { MKsz } & =\text { Magyar Könyvszemle } \\ \text { MTud } & =\text { Magyar Tudomány } \\ \text { MVízjel } & =\text { Magyar Vízjel } \\ \text { MüvtörtÉrt } & =\text { Müvészettörténeti Értesítő }\end{array}$

Alexander multifrons... = Alexander multifrons. Tanulmányok a 90 éves Dörnyei Sándor tiszteletére / szerk. Perger Péter. Bp.: OSZK-Argumentum K., 2016. 213 p. ill. (A Magyar Könyvszemle és a MOKKA-R Egyesület füzetei; 8.)

Egyház és reprezentáció = Egyház és reprezentáció a régi Magyarországon / szerk. BÁTHORY Ora régi Magyarorszá- $\quad$ solya, KóNYA Franciska. Bp.: MTA-PPKE Barokk Irod. és Lelkiség gon... Kutcsop., 2016. 433 p. ill.

Episcopus archiabbas = Episcopus archiabbas benedictinus, historicus ecclesiae. Tanulmábenedictinus, historicus nyok Várszegi Asztrik 70. születésnapjára / szerk. SomORJAI Ádám, ecclesiae... ZoMBori István. Bp.: METEM-Historia Ecclesiastica Hungarica Alapítvány, 2016. 616 p. ill.

Hatalmi diskurzusok... = Hatalmi diskurzusok. A hatalom reprezentációi a tudományokban és a mủvészetekben / KeCsKeméti Gábor et al.; szerk Bíró Csilla, Visy Beatrix. Bp.: Bibl. Nationalis Hungariae-Gondolat, 2016. 339 p. ill.

Hegyen épült város... = Hegyen épült város. Tanulmánykötet. Válogatás a Fiatal Kutatók és Doktoranduszok Nemzetközi Teológuskonferenciáján elhangzott elöadások anyagából / szerk. SzÁvAY László, GÉr András László, JENEI Péter Bp.: KGRE-L'Harmattan, 2016. 404 p. ill.

\footnotetext{
* 2014-es és 2015-ös impresszummal megjelent publikációk pótlásával.
} 
In via eruditionis... = In via eruditionis. Tanulmányok a 70 éves Imre Mihály tiszteletére / szerk. Bitskey István et al. Debrecen: Debreceni Egy. K., 2016. 538 p. ill.

„A királyhűség jól bevált = „A királyhűség jól bevált útján...”. Rendi és nemzeti kötődések szimútján..."... bolikus változásai 1967 és 1918 között / szerk. GLÄsSER Norbert, ZIMA András NAGYILLÉs Anikó közremüködésével. Szeged: MTA-SZTE Vallási Kultúrakut. Csop.-Néprajzi és Kult. Antropológiai Tansz., 2016. 490 p. ill.

Monokgraphia...

= Monokgraphia. Tanulmányok Monok István 60. születésnapjára / szerk. Nyerges Judit, VeróK Attila, Zvara Edina. Bp.: Kossuth, 2016. 847 p. ill. http://mek.oszk.hu/16200/16282/16282.pdf

Natio est semper reformanda...

= Natio est semper reformanda. Tanulmányok a 70 éves Gergely András tiszteletére / szerk. ANKA László et al. Bp.: KRE-L'Harmattan, 2016. 647 p. ill.

A nők és a régi magyar- $=$ A nők és a régi magyarországi vallásosság / szerk. BAJÁKI Rita, országi vallásosság... BÁTHORY Orsolya. Bp.: MTA-PPKE Barokk Irod. és Lelkiség Kutcsop., 2015. 437 p. ill.

Nunquam autores, semper $=$ Nunquam autores, semper interpretes. A magyarországi fordításirointerpretes... dalom a 18. században / szerk. LENGYEL Réka. Bp.: MTA BTK Irodalomtudományi Intézet, 2016. 421 p.

Propaganda. Politika, hét- = Propaganda. Politika, hétköznapi és magas kultúra, művészet és méköznapi és magas kul- dia a nagy háborúban / szerk. ifj. BERTÉNYI Iván, BOKA László, KaTONA túra, müvészet és média Anikó. Bp.: OSZK, 2016. 542 p. ill. a nagy háborúban...

Testimonio litterarum... = Testimonio litterarum. Tanulmányok Jakó Zsigmond tiszteletére / DÁNÉ Veronika, LuPescuné MaKó Mária, Sipos Gábor szerk. Kolozsvár: Erdélyi Múzeum-Egyes., 2016. 453 p.ill.

Tipográfia régtől fogva... = Tipográfia régtől fogva. A nagyváradi nyomdászat 450 éves története / szerk. BoKA László, EMŐdi András. Bp.: OSZK-Argumentum K., 2016. 158 p. ill

Történetek Baranyából... = Történetek Baranyából / szerk. GYÁNTI István, Kiss Zoltán. Pécs: Csorba Gy. Kvt,, 2016. 261 p. ill.

„Új könyvtár virul itt, = „Új könyvtár virul itt, tele rendbe rakott tudománnyal. Fontos, hogy tele rendbe rakott mindent nyitva találsz odabent.". Tudomány és kutatás a 240 éves Klimo tudománnyal. Fontos, hogy mindent nyitva Könyvtárban. A 2014. október 16-17-én rendezett jubileumi tudományos konferencia tanulmányai / szerk. Dezsö Krisztina, MolnáR Dávid, találsz odabent."...

Útmutató... SCHMElCZer-Pohánka Éva. Pécs: PTE Egy. Kvt. és Tudásközp.-Pécsi Egyházmegye, 2016. 386 p. ill. (A Pécsi Egyetemi Könyvtár kiadványai; 13.)

= Útmutató. Tanulmányok Pázmány Péter Kalauzáról / szerk. MACZÁK Ibolya. Bp.: MTA-PPKE Barokk Irod. és Lelkiség Kutcsop., 2016. 255 p. ill.

\section{Általános és összefoglaló munkák, elvi kérdések}

Alexander multifrons. Tanulmányok a 90 éves Dörnyei Sándor tiszteletére / szerk. PERger Péter. Bp.: OSZK-Argumentum K., 2016. 213 p. ill. (A Magyar Könyvszemle és a MOKKA-R Egyesület füzetei; 8.)
ALMÁsi Gábor: Egy különleges életút a 16. század első feléből. Martin Brenner, erdélyi szász humanista $=$ MKsz (132.) 2016. 1. 14-30.

BALÁzs Mihály: Túl a felekezeti határokon. Körmöczi János kapcsolatrendszeréhez = Értelmiségi karriertörténetek 2. / szerk. Bíró Annamária, BoKA László. Nagyvárad: Partium K.; Bp.: Reciti, 2016. 63-75. 
Cserey Farkas Széchényi Ferenchez, kézirata kiadatásának sikertelenségéről írt levele szövegközlésével.

BÁN Izabella: Egyházi és világi reprezentáció megjelenése a társulati imakönyvekben $=$ Egyház és reprezentáció a régi Magyarországon... 7-24.

BÁNFI Szilvia: A nagyszombati ábécéskönyv CISIO JANUS részének korábban nem ismert magyar nyelvü hónapversei $=$ ItK (120.) 2016. 1. 72-79. ill.

A nagyszombati ábécéskönyv az RMNyben 471A-ként található. A hónapversek szövegével. 76-78.

Az mi urunc Iesus Christusnac wy testamentoma. Sárospatak: Hernád, 2015. Hasonmás kiad. 236 p. + mell. (19 p. ill.)

I. Rákóczi György a könyvgyüjtő bibliaolvasó (melléklet címe).; Kész. a Sárospataki Református Nagykönyvtárban M 24 jelzeten örzött példány alapján.; A mellékletben Monok István és Dienes Dénes tanulmányával; Eredeti kiadása: Visolban : Mantskovit Balint nyomtatása által, 1590.

Bíró Csilla: Esterházy Pál nádor hatalmi reprezentációja két régi nyomtatvány tükrében $=$ Hatalmi diskurzusok... 48-62. ill.

BíRó-BALogh Tamás: Könyvvel üzenek néked. Radnóti Miklós dedikációi. Bp.: Szépmíves Könyvek K., 2016. 380 p. ill.

Bitskey István: Pázmány Péter és a Reihing-vita. Adalék az érseki könyvbeszerzéshez $=$ Monokgraphia...98-101.

BitsKey István: Kalauz mint liber gradualis = Útmutató...197-203.

BoDA Miklós: Az Erzsébet Tudományegyetem Könyvtára Balogh Károly (1879-1944) irodalomtörténész és müfordító életében $=$ „Új könyvtár virul itt, tele rendbe rakott tudománnyal. Fontos, hogy mindent nyitva találsz odabent.”... 129-146. ill.

BogÁR Judit: A felvilágosodás előzményei egy evangélikus tudós tanár, ifj. Buchholtz György munkásságában $=$ A felvilágosodás előzményei Erdélyben és Magyarországon, 1650-1750 / szerk. BALÁzs Mihály, BARTóK István. Szeged: SZTE M. Irodalmi Tanszék, 2016. 257-264.
Olvasmánytörténeti adatokkal.

BoKa László-Rózsafalvi Zsuzsanna: A szavak háborúja. = Propaganda az I. világháborúban. Az Országos Széchényi Könyvtár kiállítása, 2015. október 16-2016. április 9. / szerk. ifj. Bertényi Iván, BoKa László. Bp.: OSZK, 2016. 75-95.

Angol nyelven: 97-118.

Csorba Dávid: Az Országh Ilona feletti hiányzó temetési beszéd esete $=$ Monokgraphia... 137-142.

Csörsz Rumen István-Szilágyi N. Zsuzsa: Kintyets kimpenyesty. 1768. Egy román-magyar verses ponyva tanulságai. $=$ Nunquam autores, semper interpretes... 69-93. ill.

A Nunquam autores, semper interpretes A magyarországi fordításirodalom a 18. században c. konferencián 2014. október 3-án Miskolcon elhangzott előadás kiegészített, szerkesztett változata; Könyvészeti adatokkal

DALloul Zaynab: Una cinquecentina particolare di Bernardino Guerralda nella Biblioteca Nazionale di Budapest $=$ Le fusa del gatto (Torrita di Siena, Società Bibliografica Toscana) 2016. 85-107.

DAlloul Zaynab: Interpretations of Janus Pannonius'Eranemos in Light of the Cultural Heritage and Library of Count Sámuel Teleki and Alexander Kovásznai = Kniha (Martin, Slovenská Národná Kniznica) 2016. 182-192.

DeÉ NAGY Anikó: Teleki Sámuel végakarata = Monokgraphia... 154-162.

Teleki Sámuel végrendeletének szövegközlésével

Doncsecz Etelka: A pesti Lesegesellschaft szabályzata és tagjai $=$ MKsz (132.) 2016. 3 . 337-353.

Ecsedy Judit, V.: Egy pozsonyi könyvkiadó és rézmetsző: Johann Nepomuk Schauff (1757-1827) = MüvtörtÉrt (65.) 2016. 1 . 113-127. ill.

EGYED Emese: A fegyelmezett világ munkása. Daniele Concina a színjátszás veszedelméről = „Új könyvtár virul itt, tele rendbe rakott tudománnyal. Fontos, hogy mindent nyitva találsz odabent.”... 113-128. 
FARKAS Gábor Farkas: The Case of King's Assassination as Presented in Early Prints and Manuscripts. Was Louis II. King of Hungary. Assassinated after the Battle of Mohács (1526)? = Kniha (Martin, Slovenská Národná Kniznica) 2016. 31-39.

FeKete Csaba: A Szákiak = MKsz (132.) 2016. 1. 47-59.

GeszTEly Hermina: A női vallásosság lehetőségei és elvárt formái a hímzésmintakönyvek ajánlásai alapján a kora újkorban $=$ A nők és a régi magyarországi vallásosság... 125135.

Elhangzott előadás szerkesztett változata

GoluB Xénia: Szláv antikváink és szerb possessoraik = Hatalmi diskurzusok... 83-104. ill.

Golub Xénia: Serbian Monks as Documented by the Handwritten Inscriptions in the Early Printed Cyrillic Slavonic Books from the Territory of the Serbian Orthodox Eparchy of Buda = Niš and Byzantium.IV (Niš) 2016. 603-616.

Gudor Kund Botond: Bod Péter és a németalföldi peregrináció = Monokgraphia... 228-251. Könyvészeti adatokkal

Hamvas Endre-Keserü Bálint: Köleséri Sámuel tudományos-irodalmi fő müvének sorsa $=$ Monokgraphia... 257-259.

HargitTAY Emil: A reformáció irodalma. Könyvnyomtatás, protestáns tudományosság, bibliafordítások = Fejedelemasszonyok és a vallásszabadság Erdélyben. Tanulmánykötet és kiállítási katalógus / szerk. UdVARHELYI Erzsébet, NAGY Károly. Veszprém: Boldog Gizella Főegyházmegyei Gyüjt., 2016. 115120.

A tanulmány angol nyelvű változata: 121123.

Hegri Ádám: Die Rolle der Buchbinderprediger in der Meinungsformung von ungarischen und deutschsprachigen reformierten $\mathrm{Ge}$ meinden am Ende des 18. Jahrhunderts bezüglich der gedruckten Bücher im südöstlichen Teil des Königreichs Ungarn = Knihy v proměnách času. K výzkumu zámeckých, měšt’anských a církevních knihoven / ed. Ritka RADIMSKÁ. Česke Budějovice: Jihočeská univerzita, 2015. 94-115.
A Cesky Krumlovban 2014. október 24-26. megrendezett konferencián elhangzott elöadás szerkesztett változata

HÖRCHER Ferenc: Intézményalapítás és polgári kultúra. A Széchenyiek útja a főúri mecenatúrától a Bildungsbürger eszményéig = Nemzet, faj, kultúra a hosszú 19. században Magyarországon és Európában / szerk. Hörcher Ferenc, Lajtai Mátyás, Mester Béla. Bp.: MTA BTK TTI, 2016. 147-177., 322.

A Nemzet, faj, kultúra a hosszú 19. században Magyarországon és Európában c. konferencián 2015. december 8-án Budapesten elhangzott előadás kiegészített, szekesztett változata.

Hubert Ildikó: Feljegyzések Károlyi Gáspár haláláról. Sóvári Soós Kristóf posztilláinak kéziratos toldalékában = Monokgraphia.. 289-293. ill.

Az MTAK KIK Kézirattárában őrzött kötetben (Bártfa, 1598.) található kéziratról

JÁKI László: A ponyva szerepe az olvasóvá nevelésben. Az ,aljairodalomtól” a „,nemes ponyváig" = KN (18.) 20163 . 17-32.

JuHÁsz Zoltán: Pázmány Péter, a Kaluz és a liber gradualis = „Hiszek, hogy megértsem!”. Doktoranduszok Országos Szövetsége Hittudományi Osztály Fiatal Kutatók és Doktoranduszok IV. Nemzetközi Teológuskonferenciája. Budapest, 2013. november 30. Konferenciakötet / szerk. Gér András László, Jenei Péter, Zila Gábor. Bp.: KRE-L'Harmattan, 2015. 317-324. ill.

Karvalics László, Z: A múzsák a háborúban sem hallgatnak. Szempontok és példák egy furcsa fogalmi négyszög értelmezéséhez = Monokgraphia... 353-360.

A két világháború katonáinak olvasási szokásai, ezek hatása a tömegkultúrára és az információs társadalom kialakulására.

KATONA Anikó: Vizuális kultúra és háborús propaganda Magyarországon = Propaganda az I. világháborúban. Az Országos Széchényi Könyvtár kiállítása, 2015. október 16-2016. április 9. / szerk. ifj. BERTÉNYI Iván, BOKA László. Bp.: OSZK, 2016. 53-62.

Angol nyelven: 63-73. 
KeSERŰ Bálint: Jakó Zsigmond és a kora újkori magyar irodalom $=$ Testimonio litterarum. Tanulmányok Jakó Zsigmond tiszteletére / DÁné Veronika, Lupescuné Makó Mária, Sipos Gábor szerk. Kolozsvár: Erdélyi Múzeum-Egyes., 2016. 169-178.

KIs Krisztián Bálint: Székelyföldi nyomdák, kiadók, könyvkereskedők, újságok, folyóiratok és helyi lapok = A Csíki Székely Múzeum évkve. 2016. 89-117.

Kiss Endre József: Bodrog-parti könyvesház. Sárospatak: Hernád K., 2016. 516 p. ill.

A Sárospataki Református Nagykönyvtárhoz kapcsolódó könyv-, könyvtár-, müvelődés- és sajtótörténeti írásokkal.

KIss Péter: Az egri érseki Líceum történetéből. Eger: Kiss P., 2016. 348 p. ill. Könyvtártörténeti és nyomdatörténeti fejezettel 98165., 235-261., 291.

Kocsis Éva: Mátyás Flórián kutatásai és könyvtára Pécsett $=$ „Új könyvtár virul itt, tele rendbe rakott tudománnyal. Fontos, hogy mindent nyitva találsz odabent.”... 61-87. ill.

KösZeGHY Zsolt: Egy magyar diplomata Borisz Godunov országában: Zalánkeményi Kakas István és Georg Techtander Moszkóviája $=$ Aetas (31.) 2016. 2. Törésvonalak. 145-161.

LÁzs Sándor: Apácaműveltség Magyarországon a XV-XVI. század fordulóján. Az anyanyelvü irodalom kezdetei. Bp.: Balassi, 2016. 459 p. ill.

Lengyel Réka: A visszanyert könyvtár. A Széll Farkas-gyüjtemény feldolgozásának lehetőségei a 21. században = Monokgraphia... 473-478.

Lengyel Réka: Digitized Culture and Erudition the Library of Farkas Széll (Knihovna Kubelikova-Széllova) available on Google Books = Kniha (Martin, Slovenská Národná Kniznica) 2016. 277-283.

LiPTÁK Dorottya: Szeletek az „erdélyi” könyves- és sajtóvilág 19. századi történetéből. Pályaívek, generációk, tendenciák, várostörténeti és vállalkozástörténeti kontextusban = Monokgraphia... 491-503.
LöKÖs István: A magyar reformáció recepciója egy közép-európai nyelvi régióban $=$ In via eruditionis... 122-137.

Könyvtörténeti adatokkal

MACZÁK Ibolya: Keresztély Ágost temetése. A korabeli regensburgi kiadványok tükrében = Egyház és reprezentáció a régi Magyarországon...273-283. ill. Fényképmelléklet 278-283.

Molnár Dávid: Franconius Daniel gyüjteménye. Szövegkiadás =Vers. Verstan, poétika, trópusok a 15-17. századi Európában. Fiatalok Konferenciája 2013 / szerk. BARTóK Zsófia Ágnes et al. Bp.: Reciti, 2014. 73-77. Az előadás kiegészített, szerkesztett változata; A függelékben hat epigrammával Franconius Daniel Illustrium virorum omina című gyűjteményéből latin és magyar nyelven 75-77.

MoNOK István: Hasonlóságok és eltérések a Köztes-Európa kora újkori könyvtörténetében. Szempontok és példák = Episcopus, archiabbas benedictinus, historicus ecclesiae... 2016. 233-246.

MoNOK István: Hatalom és könyvtárak a kora újkori Magyar Királyságban és Erdélyben = In via eruditionis... 363-369.

MoNOK István: Új hatalmi viszonyok a tudományos információk megosztásában $=$ MTud (177.) 2016. 6. 690-696.

MoNoK István: A könyvtárak nyilvánossága a 16-18. században = ,Új könyvtár virul itt, tele rendbe rakott tudománnyal. Fontos, hogy mindent nyitva találsz odabent.”... 13-23.

Monokgraphia. Tanulmányok Monok István 60. születésnapjára / szerk. Nyerges Judit, VeróK Attila, Zvara Edina. Bp.: Kossuth, 2016. 847 p. ill.

NÉmETH S. Katalin: Zrínyi Miklós, a szigetvári hős gyászbeszéde, Farkasics Péter és Horváth György epitaphiuma, 1571 = ItK (120.) 2016. 5. 621-630. ill.

Könyvtörténeti adatokkal, és a hungarika szövegközlésével

Ó idők! Ó erkölcsök! Etikai és könyvtörténeti tanulmány / szerk. MACZKÓNÉ IVÁNYI Katalin, 
VASSNÉ TÉCsy Edit. Orosháza: Orosházi Táncsics M. Gimn., Szakközépisk. és Kollégium, 2016. 113 p. ill.

Egy könyvritkaság az Orosházi Táncsics Mihály Gimnázium könyvtárában: Florilegii Magni sev Polyantheae floribus novissimis sparsae, Libri XX. Frankfurt, Zetzner, 1621.

OLÁH Róbert: Adalék Geleji Katona István és Friedrich Spanheim kapcsolatához = Egyháztört. Szle (17.) 2016. 4. 123-126. ill.

Orbán János-CsöRsz RuMEN István: Kéziratok és nyomtatványok egy marosvásárhelyi kereskedőház boltozatából = Lymbus 2015 . \{2016\} 275-314. ill.

PÁL József: Temesvári Pelbárt munkásságának hatása és kutatásának története $=$ ItK (120.) 2016. 2. 191-206.

Rózsa Dávid: Az ország és népe. A magyar (állam)leíró statisztika Bél Mátyástól Fényes Elek koráig = Fényes Elektől az európai statisztikai rendszerekig. Tanulmánykötet / fel. szerk. LaczKa Éva, Szabó István. Bp.: MST; Oradea: Partiumi Területi Kutatások Int., 2016. 38-57. ill.

SARBAK Gábor: Buda és Krakkó pálos kapcsolatai a középkorban $=$ Közös úton. Budapest és Krakkó a középkorban. Kiállítási katalógus. A Budapesti Történeti Múzeum és a Muzeum Historyczne Miasta Krakowa közös kiállítása. Budapesti Történeti Múzeum Vármúzeum, 2016. március 18 - július 24. Bp.: BTM; Kraków: Muz. Historyczne Miasta Krakowa, 2016. 133-135. ill.

Simon Katalin, H: A Szombathelyi Püspökség szerepvállalása Szombathely kulturális életében a 18. század végén = „Új könyvtár virul itt, tele rendbe rakott tudománnyal. Fontos, hogy mindent nyitva találsz odabent."... 47-59. ill.

Sonnevend Péter: A hazai könyvtárügy szovjetizálása felé, 1947-1948 = KF (26.) 2016. 2. 209-226.

STUMmER János: Amszterdamtól Nagyenyedig. M. Tótfalusi Kis Miklós hányattatásai 1689 és 1698 között = Hegyen épült város... 296-301. SZÉCHENYI Ágnes: Magyar író a film világpiacán. Bíró Lajos (1880-1948) = SzÉCHENYI
Ágnes. Pályaképek. Művelődéstörténeti metszetek a 20. századból. Bp.: Corvina, 2016. 63-157.

Bíró Lajos pályaképe, benne szerkesztői, publicisztikai tevékenysége, és sajtótörténeti adatok

SzÉKELY Gábor: Egy kecskeméti peregrinus viszontagságai az osztrák örökösödési háború idején. Szatmári Pál odera-frankfurti tanulmányútja 1742-1743-ban $=$ Hegyen épült város... 195-200.

Könyvbeszerzésre vonatkozó adatokkal

Székelyföld története. Bp.: MTA BTK; Kolozsvár: EME; Székelyudvarhely: HRM, 2016. ill. [1-3. köt.] 1. köt.: A kezdetektől 1562-ig / szerk. BenKö Elek, OBoRni Teréz. 582 p.; 2. köt.: 1562-1867 / szerk. EGYED Ákos, Hermann Gusztáv Mihály, ОвоRn Teréz. 735 p.; 3. köt: 1867-1990 / szerk. BÁRDI Nándor, PÁL Judit. 859 p.

Mủvelődéstörténettel kapcsolatos könyvfejezetek, és könyvrészletek

SzÉNÁSI Zoltán: Reprezentáció és karitász. Bevezető gondolatok a Budapesti Újságírók Egyesülete Almanachjának sorozatkiadásához $=$ A Budapesti Újságírók Egyesülete ... évi almanachja; szerk. Szerdahelyi Sándor; kísérö tanulmány BoKa László, SzÉNÁsI Zoltán. Reprint kiad. Bp.: OSZK-Argumentum K., 2016. ill. 3-16.

1909-ik év.

SzVORÉNYI Róbert: Eperjesi Serédy Márton publikálatlan magyar verse és annak forrása = Alexander multifrons ... 123-127.

A verset tartalmazó kiadvány könyvtörténeti adatokkal.

„Új könyvtár virul itt, tele rendbe rakott tudománnyal. Fontos, hogy mindent nyitva találsz odabent.”. Tudomány és kutatás a 240 éves Klimo Könyvtárban. A 2014. október 1617-én rendezett jubileumi tudományos konferencia tanulmányai / szerk. Dezsö Krisztina, Molnár Dávid, Schmelczer-PohÁnKa Éva. Pécs: PTE Egy. Kvt. és Tudásközp.Pécsi Egyházmegye, 2016. 386 p. ill. (A Pécsi Egyetemi Könyvtár kiadványai; 13.) 
VÁSÁRhELYI Judit, P: Samuel Spielenberger ismeretlen verse és albumbejegyzése $=$ Alexander multifrons... 35-38. ill.

VERóK Attila: Régi nyomtatványok nyomában : hungaricumok Halléból = Auf der suche nach alten Druckwerken : Hungarica aus Halle. Eger: Líceum K., 2016. 314 p.

\section{Bibliográfiák, repertóriumok, katalógusok}

BorVöLGYI Györgyi-HegYKöZI Ilona: A magyar nyomda-, könyv-, sajtó- és könyvtártörténeti szakirodalom 2015-ben $=$ MKsz (132.) 2016. 4. 493-512.

EMöDI András: A Schola Rivulina Nagybányán fennmaradt köteteiről = Monokgraphia... 174-182. ill.

Germanico-Hungarica. Album a Régi Nyomtatványok Tára kincseiből = Album mit Schätzen aus der Sammlung Alter Drucke. / Red. von Péter EKLER, Bernadett VARGA; Bp.: Széchényi-Nationalbibliothek, 2016. 111 p. ill.

KIss Tamás: Gróf Zichy Ferenc győri püspök könyvkatalógusa 1752-ből = Primus inter omnes. Tanulmányok Bedy Vince születésének 150. évfordulójára / szerk. ARATó György, Nemes Gábor, VAJK Ádám. Győr: Győri Egyházm. Lvt., 2016. 367-381.

Függelékben: Catalogus librorum... 1752. 372-380.

Dörnyei Sándor műveinek bibliográfiája = Alexander multifrons... 185-198.

Jakó Zsigmond irodalmi munkásságának könyvészete $=$ Írás, levéltár, társadalom. Tanulmányok és források Erdély történelméhez / JAKÓ Zsigmond; szerk. DÁNÉ Veronka, FeJÉr Tamás, JAKó Klára. Bp.: MTA BTK Törttud. Int., 2016. 723-771.

JANCSÓ Árpád: Iconographia Temesvariensis 1716. Békéscsaba: Progresszív Ny., 2016. 166 p. ill.

A Nova kalandos regényei / szerk. GróB László. Máriabesnyő: Attraktor, 2016. 120 p. ill. (A magyar ponyva képes bibliográfiája)
Tibori Szabó Zoltán: A kolozsvári Minerva története és bibliográfiája. 1920-1948. Kolozsvár: Minerva Műv. Egyes., 2015. 431 p. ill.

VARga András: A Szegedi Tudományegyetem Egyetemi Könyvtár 1701-1800 közötti régi nyomtatványai $=$ Catalogus librorum veterum Bibliothecae Universitatis Szegediensis $=$ Altbücherbestand zwischen 1701-1800 der Universitätsbibliothek Szeged. Szeged: SZTE Klebelsberg K. Kvt., 2016. [6], V, 331 p. (A Kárpát-medence magyar könyvtárainak régi könyvei; 10.)

A Vörösmarty-gyüjtemény a Magyar Tudományos Akadémia Könyvtár és Információs Központ Kézirattárában és Régi Könyvek Gyüjteményében / összeáll. HorÁNYI Károly. Bp.: Argumentum K.-MTA Kvt. és Inf. Közp., 2016. 224 p. (A Magyar Tudományos Akadémia Könyvtár és Információs Központ Kézirattárának katalógusai; 25.) Vörösmarty Mihály könyveinek katalógusával és Csapodi Csaba tanulmányának (MKsz. 1956. 1.) újraközlésével

\section{Cenzúratörténet és más jogi szabályozások}

Hajnóczi Kristóf: Pier Paolo Vergerio és az indexek = Lát(szó)tér. Fiatal kutatók italianisztikai tanulmányai / szerk. MoLNÁr Annamária, Óтотт Noémi, PÁL József. Szeged: SZTE BTK Olasz Nyelvi és Irodalmi Tansz., 2016. 129-154., 374.

PAÁL Vince: A bủnvádi perrendtartás életbe léptetéséről szóló törvényjavaslat - „,sajtószakaszának" képviselőházi tárgyalása 1897ben = In medias res. (5.) 2016. 2. 262-283.

PAÁl Vince: Sajtóirányítás és -ellenőrzés Magyarországon a Nagy Háború éveiben = Propaganda. Politika, hétköznapi és magas kultúra, művészet és média a nagy háborúban / szerk. ifj. BERTÉnYI Iván, BoKA László, Katona Anikó. Bp.: OSZK, 2016. 257-272.

PogÁny György: A könyvtári állomány politikai célú megtisztítása, selejtezése 1945 után = KKK (25.) 2016. 4. 9-35. 
SÁRÁNDI Tamás:,Zzidóbarátok és szabadkőmüvesek elönyben"? Egy erdélyi napilap esete a magyar katonai közigazgatással 1940-ben = Médiakutató (16.) 2016. 1. 47-57.

Szelester NAGy László: Bél Mátyás Bars vármegye leírása címü kéziratának egyik bírálója: Pongrácz Gáspár esztergomi kanonok = Monokgraphia... 656-659.

Pongrácz Gáspár latin nyelven írt véleményének szövegközlésével.

VADERna Gábor: Gróf Dessewffy József a sajtószabadságról és a cenzúráról $=$ Lymbus 2016. 283-318.

Szövegközléssel

\section{Könyvtörténet / Kéziratosság, kódexek}

Ács Pál-PetnehÁzi Gábor: Késre menő vita 1571-ben Murád dragomán (Somlyai Balázs) és Arnoldus Manlius között = Monokgraphia... 39-45. ill.

A latin nyelvü szöveg közlésével és magyar fordításával

BABus Antal: A Szózat kéziratának története. = Szózat. Egy kézirat története / vál. és öszszeáll. Babus Antal; szerk. Bogdanov Edit. Bp.: Kossuth-MTA Kvt. és Inf. Közp., 2016. 12-16.

Az MTA KIK K721/I jelzetü kéziratáról

BÁthORY Orsolya: Armamentarium Parochorum.

Egy 17. századi Kalauz-kivonat $=$ Útmutató... 187-196. ill.

A kötet lelőhelye: Egri Főegyházmegyei Könyvtár, K VIII. 76

Bestiarium Zircense /... BoreczKy Anna bev. Bp.: OSZK, 2016. 75 p. ill.

Az Országos Széchényi Könyvtárban őrzött Cod. Lat. 506 jelzetủ kézirat utolsó 16 oldalának hasonmásával

DEÁK Eszter: Zách Ferenc és Schedius Lajos földrajzi témájú levelezése $=$ Magyarországi tudósok levelezése. Tanulmányok / szerk. SzeLESTEI N. László. Bp.: MTA-PPKE Barokk Irod. és Lelkiség Kutcsop., 2016. 41-50.

DeJcsics Konrád: Az Ernst-kódex hagiográfiai írásai Szent Márton életéről.= Ernst-kódex. Vita Sancti Martini. Legendae Sancti Stepha- ni Regis. Hasonmás kiad. Bp.: OSZK; Pannonhalma: Pannonhalmi Főapátság, 2016. Tanulmánykötet. 23-49.

Az Ernst-kódex (OSZK, Cod. Lat. 431). hasonmás kiadásának mellékleteként megjelent tanulmánykötet egyik dolgozata.

DÉrI Balázs: Az Ernst-kódex Szent Mártonról szóló írásainak latin szövege = Ernst-kódex. Vita Sancti Martini. Legendae Sancti Stephani Regis. Hasonmás kiad. Bp.: OSZK; Pannonhalma: Pannonhalmi Főapátság, 2016. Tanulmánykötet. 83-87.

Az Ernst-kódex (OSZK, Cod. Lat. 431). hasonmás kiadásának mellékleteként megjelent tanulmánykötet egyik dolgozata

Dомокоs György: Il veneziano trecentesco del codice dantesco di Budapest. Alcune fonti modenesi sui rapporti musicali e teatrali nel Rinascimento ungherese = Italia nostra . Studi filologici italo-ungheresi / a cura di Ágnes Ludmann. Bp.: ELTE Eötvös J. Collegium, 2016. 148-160.

Dobai Székely Sámuel és Koller József levelezése / sajtó alá rend., bev., jegyz. Hencz Enikő. Piliscsaba: PPKE BTK, 2016. 110 p. (Pázmány irodalmi műhely. Források)

A levelek egyik témája: könyvek vásárlása

DukKon Ágnes: Ostrosith Mátyás koronaőr naplója, 1673-1675 = MKsz (132.) 2016. 1. 60-71.

EKLeR Péter: Findings on the text of the Bessarion Corvina codex. Budapest, National Széchényi Library, Cod. Lat. 438. = Byzanz und das Abendland IV. Studia ByzantinoOccidentalia / hrsg. von Erika JuHÁsz. Bp.: Eötvös József Collegium, 2016. 143-148. ill. Az előadás kiegészített, szerkesztett változata

Ernst-kódex. Vita Sancti Martini. Legendae Sancti Stephani Regis. Hasonmás kiad. Bp.: OSZK; Pannonhalma: Pannonhalmi Főapátság, 2016. 250 p. ill.

A mellékletben szereplö tanulmánykötetet szerk. Déri Balázs; Készült az Országos Széchényi Könyvtár Kézirattárában őrzött Cod. Lat. 431. jelzetü kézirat alapján

Falvay Dávid: Codici italiani tra Constantinopoli e Budapest = Italia nostra. Studi filo- 
logici italo-ungheresi / a cura di Ágnes LudMann. Bp.: ELTE Eötvös J. Collegium, 2016. 95-109.

FARKAS Gábor Farkas: Dudith András és Jethro Tull = Monokgraphia... 17-21.

Hende Fanni-Korondi Ágnes: Gyógyító szavak és füvek. Egy XVI. század eleji kéziratos receptgyüjtemény margójára = Alexander multifrons... 103-108.

A budapesti Egyetemi Könyvtár Inc. 809 jelzetü dokumentumában található kéziratos receptgyüjteményről, az incubus és subcubus távoltartását szolgáló latin nyelvű szöveg szövegközlésével

HoráNYI Elek: Horányi Elek levelezése / sajtó alá rend., bev., jegyz. SzelesteI N. László. Piliscsaba: PPKE BTK, 2016. 149 p. (Pázmány irodalmi mühely. Források; 8.)

Müvelődéstörténeti, kiadástörténeti forrásanyag

Katona Tünde: Kellemes szomszédság. Összetartozó emlékkönyvbejegyzésekről = Monokgraphia... 361-365.

KerTÉsz Balázs: A magyarországi obszerváns ferences vikária 1499. évi konstitúciói = MKsz (132.) 2016. 3. 257-270.

KerTész Balázs: A 14. századi magyarországi krónika-szerkesztmények utóélete a késői középkorban = Századok (150.) 2016. 2. 473-499.

KIRÁLY Péter: Johannes Thesselius kottás bejegyzése Clemens Hizler emlékkönyvébe (1611) = Monokgraphia... 371-379.

KISDI Klára-LAUF Judit: Gyógyír a püspöknek. Az orvosi receptek titkai Filipec János pontifikáléjában = Alexander multifrons... 109116.

Függelékben: A latin nyelvű receptek

KISS FARKAs Gábor: Boëthius Besztercén. Egy ismeretlen latin költemény a 15. század második feléből $=$ MKsz (132.) 2016. 3 . 354-365.

A weimari Herzogin Anna Amalie Bibliothek Q 109/9 jelzetű kézirata és az ELTE Egyetemi Könyvtárban őrzött Breviarium Strigoniense (1484) példányának néhány tartalmi egységéröl; Latin nyelvü tartalmak szövegközlésével
KoRONDI Ágnes: Misztika a késő középkori magyar nyelvü kolostori kódexirodalomban. Misztikarecepció avagy irodalmi kegyességi gyakorlat a késő középkori magyar nyelvü kolostori kódexek devocionális szövegeiben. Kolozsvár: Egyetemi Mühely Kiadó-Bolyai Társaság, 2016. 461 p. ill. (Monográfiák; 3.)

KöRMENDY Kinga: Az esztergomi székesegyházi könyvtár orvosi kódexe az 1543 elötti könyvállományban $=$ Alexander multifrons... 25-28.

Az ÖNB Cod. 3959 jelzetủ orvosi kódexéröl

KöRMENDY Kinga: Enyedi Szász György és Lippai Mihály padovai baráti köre. Jacobus de Zocchis Ab excommunicatio repetitiója = Testimonio litterarum...199-210.

Az ÖNB 5107 jelzetű kódexének törzsanyagáról

KRUPPA Tamás: Történetíró Róma (?) városában. Egy tervezett (?) Erdély-történet nyomában = Monokgraphia... 447-453.

Az Erdély történetével foglalkozó olasz nyelvü levél szövegközlésével

Lengyel Réka: A Petrarca-hagyaték sorsa és a De remediis utriusque fortunae 14. századi másolatai $=$ Lát(szó)tér. Fiatal kutatók italianisztikai tanulmányai / szerk. MoLnÁR Annamária, Óтотт Noémi, PÁl József. Szeged: SZTE BTK Olasz Nyelvi és Irodalmi Tansz., 2016. 71-86., 375.

MadAs Edit: Szent Márton chablis-i gyógyító csodája az Ernst-kódexben. Mit keres egy magyar gróf Burgundiában a honfoglalás korában? = Alexander multifrons...29-34. Az OSZK Cod. Lat. 431 jelzetü dokumentumban (Ernst-kódex) olvasható gyógyító csodáról, a kódex vonatkozó szövegének közlésével.

MadAs Edit: Az Ernst-kódex leírása = Ernstkódex. Vita Sancti Martini. Legendae Sancti Stephani Regis. Hasonmás kiad. Bp.: OSZK; Pannonhalma: Pannonhalmi Főapátság, 2016. Tanulmánykötet 11-21.

Az Ernst-kódex (OSZK, Cod. Lat. 431) hasonmás kiadásának mellékleteként megjelent tanulmánykötet egyik dolgozata 
Mezei Zsolt: Válogatás gyüjteményünk kincseiből. 1. = Acta Papensia (16.) 2016. 1/2. 213-224. ill.

MolnÁR Antal: Magyarországi obszerváns ferences formuláskönyvek a 16 . század elejéröl = Episcopus, archiabbas benedictinus, historicus ecclesiae... 203-212.

MolnÁR Dávid: Fodor István szerémi püspök elveszett könyvtárának egyik kötete. Nicolaus de Mirabilibus De providentiájának prágai kézirata $=$ MKsz (132.) 2016. 3. 366-367.

Penke Olga: „Az olvasás szörnyü veszélyei.” Rejtőző kéziratos Voltaire-másolatok feltárása. Adalékok Galánthai Fekete János pályaképéhez = MKsz (132.) 2016. 3. $298-$ 318.

Voltaire magyarországi recepciójához

Pócs Dániel: Handó György könyvtára = Ars Hungarica (42.) 2016. 4. 309-338. ill.

A Függelékben Handó György könyvtárából fennmaradt kódexek katalógusa

RitoóKnÉ Szalay Ágnes: Janus Pannonius kéziratainak útja Zágrábtól Gyulafehérvárig = Testimonio litterarum... 355-364. ill.

SALGó Ágnes, W.: Amiről a régi könyvek mesélnek = Collectanea Sancti Martini (4.) 2016. 49-69. ill.

SzAKÁcs Béla Zsolt: The visual world of the Hungarian Angevin legendary / [transl. Lara Strong]. Bp.; New York, N.Y.: CEU Press, 2016. IX, 339 p. ill. (Central European cultural heritage; 1.)

A Balassi Kiadónál 2006-ban megjelent A Magyar Anjou legendárium képi rendszerei c. kötet angol nyelvü változata

Szoliva Gábriel: „....secundum modum Ecclesiae Zagrabiensis”. Egy középkori psaltérium metamorfózisa $=$ Monokgraphia... 673-679.

SzovÁk Kornél: A kódex szövegének helye az István-legendák hagyományozódástörténetében $=$ Ernst-kódex. Vita Sancti Martini. Legendae Sancti Stephani Regis. Hasonmás kiad. Bp.: OSZK; Pannonhalma: Pannonhalmi Főapátság, 2016. Tanulmánykötet 89-99.
Az Ernst-kódex (OSZK, Cod. Lat. 431) hasonmás kiadásának mellékleteként megjelent tanulmánykötet egyik dolgozata

То́тн Zsombor: Bethlen Miklós élettörténetének használata a kéziratos kultúrában, 17101858/60.Vázlat egy folyamatban lévő kutatás tanulságairól = ItK (120.) 2016. 3. 279-298. Függelék: A Bethlen-kódexek és a Bethlen Miklós élete leírása magától másolati példányai

WeHLi Tünde: Megjegyzések a középkori zágrábi székeskáptalan néhány liturgikus kódexéhez = MủvtörtÉrt (65.) 2016. 1. 5-25. ill.

Zvara Edina: Trenk Frigyes magyar nyelvü kiadatlan politikai röpirata $=$ Lymbus 2016 . 265-282. ill.

Szövegközléssel.

\section{Nyomda-, nyomdászattörténet}

\section{Több évszázadot érintő munkák}

BÁNFI Szilvia: A debreceni városi nyomda évszázadokat átölelő első korszaka. 1561-1705 = MG (60.) 2016. 2. 56-61. ill.

ECSEDY Judit, V.: Arcképek a hazai nyomdászattörténetből $=$ MG (60.) 2016. 3. 52-57. ill.

PERSOVITS József: Betüről-betüre. Írások a könyvnyomtatás világából. Bp.: Optima Téka K., 2016. 152 p. ill.

Róтн András Lajos: Ne utáld meg az aranyat, azért mert szurkos erszényben vagyon (menda graviora sic corrigenda) $=$ A Csíki Székely Múz. évkve. 2016. 169-192. ill.

Tipográfia régtől fogva. A nagyváradi nyomdászat 450 éves története / szerk. BoKA László, EMÖDI András. Bp.: OSZK-Argumentum K., 2016. 158 p. ill

\section{5. század}

BÁnfi Szilvia-Ecsedy Judit, V.: Az első magyarországi ősnyomda. Andreas Hess budai mühelye. 1472-1473 = MG (60.) 2016. 5-6. 98-103. ill. 
16. század

BÁNFI Szilvia: A váradi nyomdászat kezdete és 16. századi története $=$ Tipográfia régtől fogva... 9-21. ill.

ECSEDy Judit, V.-BÁNFI Szilvia: A Sárvár-újszigeti Sylvester nyomda. 1536-1541 = MG (60.) 2016. 1. 68-70. ill.

\section{7. század}

Ecsedy Judit, V.: A váradi könyvnyomtatás virágkora. Szenci Kertész Ábrahám a váradi református egyház nyomdájának élén. 1639/1640-1660 = Tipográfia régtől fogva... 22-48. ill.

KovÁcs András: A gyulafehérvári fejedelmi nyomda és szomszédsága $=$ Testimonio litterarum... 179-188.

\section{7-18. század}

BÁNFI Szilvia: A hatalmi harc áldozatául esett tipográfus. Töltési István tragikus véget ért debreceni működéséről és a meg nem valósult bibliakiadásról = Hatalmi diskurzusok... 38-47. ill.

PAPP Ingrid: Egy felső-magyarországi könyvmühely szerepe a 17. századi lutheránus reprezentációban = Egyház és reprezentáció a régi Magyarországon... 315-323.

18. század

ECSEDy Judit, V.: Az egri könyvnyomtatás kezdetei. $1755=$ MG (60.) 2016. 2. 52-54. ill.

ECSEDY Judit, V.: A veszprémi nyomdászat kezdetei.1789 = MG (60.) 2016. 2. 64-65. ill.

EMŐDI András: A katolikus papnevelde (szeminárium) nyomdájának hat évtizede. 1740/ 1744-1804 = Tipográfia régtől fogva... 49-82. ill.

20. század

BOKA László: Nyomdászattörténeti körkép Nagyváradon a 20. század első felében = Tipográfia régtől fogva...107-158. ill.

\section{Könyvmúvészet, illusztráció, ex libris}

BÁNFI Szilvia: Binder János Fülöp metszetei a máriaradnai kegyképről a budai Landerer-nyomda kiadványaiban. 1762-1771= MüvtörtÉrt (65.) 2016. 1. 99-111. ill.

A Függelékben Binder János Fülöp mária radnai kegyképet ábrázoló metszeteit tartalmazó, és a budai Landerer-nyomdából kikerülő nyomtatványok jegyzéke

BodNÁr Szilvia: „Pusztán fekete vonalakkal”.

Dürer-metszetek a Szépművészeti Múzeum gyüjteményéből = Dürer. Metszetek a Szépmüvészeti Múzeum gyűjteményéből = Prints from the collection of the Museum of Fine Arts. Kiállítás Vaszary Galéria, Balatonfüred, 2016. március 19-június 19. = Exhibition Vaszary Gallery, Balatonfüred, 19 March - 19 June 2016 / [...] rend. [...] BodnÁR Szilvia. Balatonfüred: Balatonfüred Kult. Nonprofit Kft.- Balatonfüred Városért Közalapítvány, 2016. 7-24. ill.

Angol nyelven 25-41.

CsobÁn Endre Attila: Nutrix ejus Terra est. Alkímiai, orvosi szimbólumok egy XVII. századi díszcímlapon $=$ Alexander multifrons.. 153-160. ill.

Mıкó Árpád: A Bibliotheca Corvina és II. Ulászló. A miniatúrafestészet kérdései a Jagellókori Magyarországon $=$ Testimonio litterarum... 269-278.

MoLnÁR Dávid: A történetírás ártatlanságáról Zsámboky János egyik emblémája kapcsán = In via eruditionis... 373-383. ill.

NAGY Eszter: On the creation of the gradual of King Matthias $=$ Acta historiae artium Academiae Scientiarum Hungaricae (57.) 2016. 23-82. ill.

Orgován Kinga Mária: Kiss József költeményeinek 1897. évi díszkiadásához készült illusztrációk, különös tekintettel Ferenczy Károly müveire $=$ Index. Válogatott tanulmányok a Mika Sándor Emlékülésről / szerk. SiMONKAY Márton. Bp.: Mika S. Egyes., 2016. 79-117. ill.

Regele Tímea: Semper bonis artibus - Ex librisek a Tóth Lajos Könyvtár és az Elöd Könyvtár gyüjteményében $=$ Orvosi kvtak 
(13.) 2016. Klsz. Jubileumi tanulmányok. A Pécsi Tudományegyetem Egyetemi Könyvtár és Tudásközpont Pekár Mihály Orvosi és Élettudományi Szakkönyvtár alapításának 90 évfordulójára. 48-59. ill.

Elhangzott a 2016. szept. 30-án megrendezett emlékülésen

Simon Melinda: A jelvényrajzoló Müller József $=$ MKsz (132.) 2016. 2. 221-222. ill.

Simon Melinda: Felgyürt ingujj helyett vasalt köpeny. A nyomda- és nyomdászábrázolások átalakulása a 19-20. század fordulóján = Monokgraphia... 630-636. ill.

Tegzes Ferenc: A Világháború Heti Postája képanyaga. Egy újabb érték a Klimo Könyvtár kincses ládájából = „Új könyvtár virul itt, tele rendbe rakott tudománnyal. Fontos, hogy mindent nyitva találsz odabent.”... 177-197. ill.

Tüskés Anna: A nagyszombati Szent Miklós székesegyház kegyképének tisztelete $=$ Egyház és reprezentáció a régi Magyarországon... 397-409. ill.

VASNÉ Tóth Kornélia: Világi és egyházi reprezentáció, hatalmi szimbolika az ex libriseken $=$ Hatalmi diskurzusok... 105-118. ill.

Virágszirmok, madárszárnyak. Meidzsi-kori japán fametszetek és fametszetes könyvek a Képzőmüvészeti Egyetem Könyvtárának anyagából a Dornyai Béla Múzeumban = Flower petals, bird wings. Japanese woodblock prints and woodblock printed books from the Meiji period from the collections of the Library of the Hungarian University of Fine Arts in the Dornyay Béla Museum / a kiállítás kurátorai BINCsIK Mónika, SHAH Gabriella, B. MAJKó Katalin; szerk. BincsiK Mónika. Bp.: MKE, 2016. 119 p. ill.

A kiállítást Salgótarjánban, 2016. ápr. 15jún. 28. között tartották

\section{Kisnyomtatványok}

Ecsedy Judit, V.: Schauff pozsonyi könyvkiadó kétnyelvü hirdetése. 1790. Monokgraphia... 170-173. ill.
Schauff latin és német nyelven megjelent hirdetésének szövegközlésével

ETÉNYI Nóra, G.: Diplomaták és nyomtatványok a regensburgi birodalmi gyűlésen 1685ben $=$ Müvészet és mesterség. Tisztelgő kötet R. Várkonyi Ágnes emlékére / szerk. Horn Ildikó et al. Bp.: L'Harmattan, 2016. 363-391. ill.

FAzeKas Csaba: Egy egyházpolitikai röpirat utóélete 1848-ban = Egyháztört.Szle (17.) 2016. 3. 84-89.

FeKeTE Dávid: A filmplakátok néhány korabeli megjelenése $=$ A magyar hangosfilm plakátjai, 1931-1944 / szerk. FeKete Dávid. Győr: Dr. Kovács Pál Megyei Kvtár és Közösségi Tér-OSZK, 2016. 75-94. ill.

KASZA Péter: Megjegyzések Tranquillus Andronicus 1541 -es törökellenes beszédéről $=$ In via eruditionis... 40-49.

Kiadástörténeti adatokkal

Katona Anikó: „Hódító körútra indul...”. Emblematikus sörplakátok = Tempevölgy (7.) 2016. 2. 78-83. ill.

Kopcsay Ágnes: Az Országos Széchényi Könyvtár Plakát- és Kisnyomtatványtára, különös tekintettel a grafikai plakátgyüjteményre = A magyar hangosfilm plakátjai, 1931-1944 / szerk. Fekete Dávid. Győr: Dr. Kovács Pál Megyei Kvtár és Közösségi Tér-OSZK, 2016. 95-105. ill.

Kurutz Márton-Varga Katalin-Fekete Dávid: A magyar hangosfilmkorszak plakátkultúrája = A magyar hangosfilm plakátjai, 1931-1944 / szerk. Fekete Dávid. Győr: Dr. Kovács Pál Megyei Kvtár és Közösségi Tér-OSZK, 2016. 57-74. ill.

Móré Tünde: A búcsúztató kiadványok szerepe a 16. századi egyetemjárásban $=$ Gerundium (7.) 2016. 1-2. 79-85.

MóRÉ Tünde: A wittenbergi peregrinus diákok búcsúztatása Szikszai Fabricius Balázshoz és Mágocsy Andráshoz 1562-ből = In via eruditionis... 50-58.

NAGY Andor: Adalékok a brassói szász polgárok 17. századi kapcsolattörténetéhez az alkalmi nyomtatványok alapján = Szöveg, hordozó, közösség. Olvasóközönség és közösségi ol- 
vasmányok a régi magyar irodalomban. Fiatalok Konferenciája 2015 / szerk. GESZTELYI Hermina, Görög Dániel, Maróthy Szilvia. Bp.: Reciti, 2016. 215-228. ill.

A függelékben a vizsgált korszakból származó lakodalmi köszöntők és halotti búcsúztatók listája

http://reciti.hu/2016/3826

NAGY Andor: A Trausch-gyűjtemény alkalmi nyomtatványai $=$ MKsz (132.) 2016. 3. 271-283.

Petercsák Tivadar: Első világháborús propaganda képeslapok = ,A királyhüség jól bevált útján..."... 337-348. ill.

\section{Térképészet}

GyULAI Éva: Két 19. századi Miskolc-térkép. Bécsi kadétok kéziratos katonai térképe 1854, ÖNB és Adler Károly fömérnök kataszteri térképének másolata 1880 k., BAZML. Elötanulmány a Herman Ottó Múzeum új várostörténeti kiállításához $=$ Történelem és Muzeológia (3.) 2016. 1. 103-114. ill.

HoRváth István: Térképészet a Pécsi Papnevelő Intézet uradalmában a 18-19. században $=$ Episcopus, archiabbas benedictinus, historicus ecclesiae... 247-259. ill.

HoRvÁTH István: Az urbárium végrehajtásának térképészeti munkálatai a Pécsi Papnevelő Intézet uradalmában $=$ Történetek Baranyából / szerk. GYÁNTI István, Kiss Zoltán. Pécs: Csorba Gy. Kvt., 2016. 20-28. ill.

KLINGHAMmER István: A reneszánsztól a reformáció koráig a topográfiai térképezés kialakulása $=$ GeodKart (68.) 2016. 11-12. 4-7. ill.

KLINGHAMMER István: Az égi glóbuszok történetéből... = MTud (177.) 2016. 1. 84-87.

PlihÁL Katalin: Nyomtatott magyar föld- és éggömbök, 1840-1990 / a DVD-mellékletet kész. Gede Mátyás. Bp.: Zrínyi, 2016. 231 p. ill. + DVD-ROM

SAMU Botond Gergő: Láncra vert gyarmatok, civakodó ebek, Szent Háború és az antant acélgyürüje. Az első világháborús nemzetkö- zi propaganda térképeken $=$ Propaganda. Politika, hétköznapi és magas kultúra, müvészet és média a nagy háborúban... 517-542. ill. Segyevy Dániel Zoltán: Térképművek Trianon árnyékában. Magyarország néprajzi térképe, 1918. Bp.: KSH Kvt., 2016. 235 p. ill. (A Statisztika történetei; 3.)

\section{Papír}

AnNus Sándor: A magyarországi papíripar öszszefoglaló története. 1530-2010 Bp.: Optima Téka, 2016. 178 p. ill.

HoRvÁth József: Erdély és Kárpátalja papírmalmaiban készített merített papírok vízjeleinek gyüjteménye. 16-19. század. 15451868. Bp: Magánkiad., 2016. 3 db (825 p.)

PelBárt Jenő: Poprádi Hamburger hirdetés 1900ból = MVízjel (14.) 2016. 34. 5-6. ill.

Pelbárt Jenő: Betű-vízjelek = MVízjel (14.) 2016. 34. 7-10. ill.

Pelbárt Jenő: A Diósgyőri Papírgyár tölgyleveles vízjel-védjegyének alakváltozatai 1900 1949 = MVízjel (14.) 2016. 34. 11-36. ill.

PeLBÁRT Jenő: Külföldi levélpapír-vízjelek különgyüjteménye az MVA-ban. Greschik-vízjelek 1. rész = MVízjel (14.) 2016. 34. 43-50. ill.

Pelbárt Jenő: Szám-vízjelek-vízjelszámok = MVízjel (14.) 2016. 35. 13-44. ill.

PeLBÁRT Jenő: Külföldi levélpapír-vízjelek különgyüjteménye az MVA-ban. Greschik-vízjelek 2. rész = MVízjel (14.) 2016. 35. 45-50. ill.

Pelbárt Jenő: Original Antique Post, 1902 = MVízjel (14.) 2016. 36. 5-6. ill.

Pelbárt Jenő: Monogram-vízjelek. 1. rész = MVízjel (14.) 2016. 36. 7-10. ill.

PelbÁRT Jenő: RJE koronázási levélpapír 1908ból = MVízjel (14.) 2016. 36. 11. ill.

PelBárt Jenő: Papírkészítő-vízjel, 1931 = MVízjel (14.) 2016. 36. 12. ill.

Pelbárt Jenő: Külföldi levélpapír-vízjelek különgyüjteménye az MVA-ban. Greschik-vízjelek. 3. rész $=$ MVízjel (14.) 2016. 36. 13-20. ill.

Pelbárt Jenő: Dejte papírmalom koronás magyar címer-vízjelei az 1793-1876 közötti 
időszakból = MVízjel (14.) 2016. 36. 2124. ill.

PelbÁRt Jenő: Hrabóc papírmalom vízjelpárja 1808-ból = MVízjel (14.) 2016. 36. 25-26. ill.

PelbáRT Jenő: Lukó papírmalom vízjelpárjai az 1793-1846 közötti időből = MVízjel (14.) 2016. 36. 27-30. ill.

PelbÁrt Jenő: Felsőruzsbach papírmalom két XIX. századi koronás magyar címer-vízjele = MVízjel (14.) 2016. 36. 31-32. ill.

PeLBÁRT Jenő: Zólyomlipcse-1. papírmalom vízjelhasználata (1664-1846) = MVízjel (14.) 2016. 36. 39-50. ill.

PelbÁrt Jenő: Ótura papírmalom koronás magyar címer-vízjele, 1847 = MVízjel (14.) 2016. 37. 6. ill.

PelbáRt Jenő: Szénási Lászlóné különgyüjtemény az MVA-ban. Szénási-vízjelek 1. rész = MVízjel (14.) 2016. 37. 31-50. ill.

PelbÁRt Jenő: Wilhelm Hamburger, rokonai és utódai szerepe a magyar papíriparban $=\mathrm{Pa}$ píripar (9.) 2016. 1. 5-16. ill.

\section{Könyvkötés-történet}

BORDÉ Katalin: Kner Erzsébet, a világhírü könyvkötőművész és a női vállalkozók előfutára = Szabolcs-Szatmár-Beregi Szle (51.) 2016. 2. 80-95. ill.

Mıкó Árpád: A Bibliotheca Corviniana és az aranyozott corvina-kötések $=$ Monokgraphia... 510-514.

RozSONDAI Marianne: Erdélyi kötések további csoportjai a 17. századból = Monokgraphia...604-609. ill.

Rozsondai Marianne: A gyulafehérvári fejedelmi nyomda kiadványainak eredeti bőrkötései $=$ Testimonio litterarum... 365378. ill.

То́тн Zsuzsanna: Egy könyvről... = Monokgraphia... 700-705. ill.

Laurentius Beyerlinck, Promotuarium morale....Köln, 1618. c. kiadvány német reneszánsz kötéséről

\section{Könyvkereskedelem-terjesztés}

Simon Melinda: Hoffmann Alfréd és a dualizmus könyvkereskedelme. Bp.: Balassi, 2016. 502 p. ill.

\section{Kiadástörténet}

\section{Több évszázadot érintő munkák}

Bogár Judit: Pázmány Péter Imádságos könyvének kiadásai és a reprezentáció = Egyház és reprezentáció a régi Magyarországon... 59-77. ill.

Csernus Sándor: Jean de Joinville történetének kéziratai, első kiadásai és a könyvnyomtatók felelőssége = Monokgraphia... 132-136.

KAPRONCZAY Katalin: Fejezetek az orvosi bibliográfia, lexikográfia múltjából = Alexander multifrons... 77-84. ill.

MonoK István: La Hongrie et l'édition alsacienne, 1482-1621. Conjoncture éditoriale et évolution des représentations d'un pays $=$ Histoire et civilisation du livre (10.) 2015. 51-72.

SzovÁk Kornél: A Váradi Regisztrum kiadásai és filológiája $=$ Mortun falu. 800 éves Kunszentmárton, 1215-2015 / szerk. BARNA Gábor. Kunszentmárton: Helytört. Múz., 2016. 44-60.

SzŰCs Kata Ágnes: Adalékok Árpád-házi és Portugáliai Szent Erzsébet kora újkori ikonográfiájához. Johannes Molanus $=\mathrm{MKsz}$ (132.) 2016. 4. 385-403. ill.

\section{5-16. század}

JANKOVITS László: Vizsgálódások Jacobus Piso és a bécsi Ausonius-kiadás körül $=$ Monokgraphia... 337-340.

16. század

BARTók István: „...széthúzások pusztító viharában...”. Adalékok Sylvester János Újszövet- 
ségfordításának bécsi kiadásához $=$ In via eruditionis... 101-105.

Berkes Katalin: Mit olvastak még, akik ezt olvasták? Enyedi György Aithiopika-fordításához kapcsolódó művek = Enyedi 460. Tanulmánykötet Enyedi György születésének 460. évfordulójára rendezett kamarakonferencia előadásaiból / szerk. K. KAPOSI Krisztina, Lovas Borbála. Bp.: MTA-ELTE HECE, 2016. 27-40.

KIss FARKAS Gábor: Az első, részben magyar nyelvü nyomtatvány. Melanchthon: Elementa Latinae grammatices, Krakkó, Vietor, 1526 = Monokgraphia... 375-379.

KIss FarKas Gábor: Sylvester János első verse $=$ MKsz (132.) 2016. 1. 72-74.

A Jagelló-könyvtár és a Zamoyski-könyvtár egykori vezetőjének magángyüjteményéből származó egy-egy példányról

MÁté Ágnes: Az Eurialus és Lucretia széphistória latin forrása $=\operatorname{ItK}$ (120.) 2016. 2. 147-165. Könyvtörténeti, kiadástörténeti adatokkal

Perger Péter: Zsámboky János Plautus-edíciójának ismeretlen kiadása és hazai olvasója = Alexander multifrons... 119-122.

\section{6-17. század}

Hevesi Andrea: Az egyházi reprezentáció és az önreprezentáció kapcsolata a 16-17. századi protestáns gyülekezeti énekeskönyvekben. A 17. század végi kolozsvári unitárius nyomda $=$ Egyház és reprezentáció a régi Magyarországon... 133-141.

\section{7. század}

BARTA M. János: Csáky István (1635-1699) és a Politica philosophiai okoskodás $=$ Századok (150.) 2016. 4. 891-909.

Boda Miklós: Adriai tengernek Syrenaia, anno M.DC.LI. „Groff Zrini Miklos” költeményeinek bécsi kiadásáról - kérdőjelekkel = Jelenkor (59.) 2016. 9. 920-930. ill.

Bojtos Anita: Epizód a magyar vonatkozású bécsi könyvkiadás XVII. századi történetéből. Gregorius Coelius Pannonius Énekek éneke-kommentárja = Habitus. Tanulmá- nyok a Colloquium Officiale II konferencia előadásaiból / szerk. BARÁth Dóra, KIsS Alpár. Bp.: Mika S. Egyes., 2016. 111-142.

ETÉNYI Nóra, G.: Aktualitás és reprezentáció. Matthäus Wagner (1648-1694) ulmi kiadó almanach royaljai $=$ Monokgraphia... 183189. ill.

GÁBor Csilla: Szerző, fordító, patrónus - Zólyomi Boldizsár Gerhard-fordításának hátteréhez $=$ In via eruditionis ...115-121.

HuBERT Gabriella, H: Keresztyéni énekek. Debrecen, 1610 = In via eruditionis... 201-210.

PÁlffy Géza: Két elfeledett hungarikum keletkezéséről = Monokgraphia... 554-561. ill.

PÉnzes Tiborc Szabolcs: Egy lépés a Medgyesi kritikai kiadás felé - Lorántffy Zsuzsanna: Moses es az prophetak = In via eruditionis... 325-333.

A Moses és a prophetak szerzőségéről

Restás Attila: Két ismeretlen strassburgi nyomtatvány. Michael Joannes Moslehner magyar nyelvü verse (1633) és Joannes Kempius jogi disputációja (1632). Pótlás az RMNy-hez, az RMK-hoz és az RMSz-hez $=$ In via eruditionis...74-81. ill.

VÁsÁrhely Judit, P.: Újabb, eddig ismeretlen bártfai evangélikus énekeskönyv a 17. századból - RMNy S $1759=$ MKsz (132.) 2016. 1. 75-80.

Az OSZK RNYT RMK I 686b=E 205 jelzetü példányáról (az RMNy S 1759 A kötete)

\section{7-18. század}

KnAPP Éva: Martin von Cochem Magyarországon. Zebegény: Borda Antikvárium, 2014 2. rész: Pótlások és kiegészítések az első részhez, Jó illatú kis rózsáskertek, Sigray Erzsébet Róza Jó illatú rózsáskertje. 2016. 267 p. (Régi magyarországi vallásos nyomtatványok; 2.)

\section{8. század}

BAJÁKI Rita: Kalauz, Liber Petri Pazmani Cardinalis. Az 1760-ban megjelent egri kiadás sajátosságai $=$ Útmutató... 173-186. ill. 
BARTA János (ifj.): Nyelvváltás a 18. század végi magyarországi mezőgazdasági irodalomban = In via eruditionis .. 90-98.

A magyar nyelvü mezőgazdasági irodalom kiadástörténetéhez

BITSKey István: Dictionarium quadrilingue $=$ In via eruditionis... 260-270.

Csörsz Rumen István: A kesergő nimfától a fonóházi dalokig. Közköltészeti hatások a magyar irodalomban, 1700-1800. Bp.: Universitas, 2016. 446 p. (Irodalomtudomány és kritika. Tanulmányok). II.7. Az első magyar lírai antológia. A váci Énekes Gyüjtemény (1799, 1801, 1803, 1823). 353-380.; II.7. Kiadástörténet. 355-359.

EGYED Emese: Müvelt nemesek és tudós pártfogoltak könyvkiadási szokásai a XVIII. századi Erdélyben = Müveltség és társadalmi szerepek. Arisztokraták Magyarországon és Európában / szerk. BÁRÁNY Attila et al. Debrecen: DE Tört. Int., 2014. 473-483.

Hegri Ádám:,,...le fordította és ki is nyomtattatta... de a mellybe sok kárt vallott...". Szalay Pál fordításai és a 18. századi könyvkiadás $=$ Nunquam autores, semper interpretes... 255-268.

A Nunquam autores, semper interpretes A magyarországi fordításirodalom a 18. században c. konferencián 2014. október 1-én Miskolcon elhangzott előadás kiegészített, szerkesztett változata

KNAPP Éva: Sigray Erzsébet Róza Jó illatú rózsakert-fordításának (1703) keletkezéstörténetéhez $=$ ItK (120.) 2016. 4. 468-502. ill. A tanulmány bővített változata egyidejüleg megjelent a szerző Martin von Cochem Magyarországon c. munkájának második kötetében

KNAPP Éva: VI. Pius pápa imádságos könyve: Magyarul és Magyarországon = Nunquam autores, semper interpretes... 146-189. ill. A magyarországi fordításirodalom a 18. században c. konferencián 2014. október 1-én Miskolcon elhangzott előadás kiegészített, szerkesztett változata.

LeNGYel Réka: Kónyi János elcserélt fordítása. A bölcsességnek és jó erkölcsnek könyve, 1774. Robert Dodsley magyarországi re- cepciójához $=$ Nunquam autores, semper interpretes... 128-145. ill.

A Nunquam autores, semper interpretes A magyarországi fordításirodalom a 18. században c. konferencián 2014. október 3-án Miskolcon elhangzott előadás kiegészített, szerkesztett változata

PÁlfy Eszter: Gyöngyösi István és Tétsi N. Zakariás - a Murányi Vénus 1702-es kiadásáról = MKsz (132.) 2016. 4. 445-462. ill.

SIPOS Gábor: A Kiss catechismus ismeretlen kiadásának sajátos példányáról $=$ Monokgraphia... 649-650.

SzÁRAz Orsolya: Missziós énekeskönyv a 18. századi jezsuita népmisszókban $=$ In via eruditionis... 225-239.

A magyar missziós énekeskönyvek kiadástörténetéhez.

Szelestei Nagy László: Séllyei Nagy Ignác székesfehérvári püspök két imakönyvéröl. 1780, $1789=$ MKsz (132.) 2016. 3. 319 336. ill.

\section{9. század}

Dомокоs Mariann: Szóbeli mesék 19. századi nyomtatott forrásai = Ethnographia (127.) 2016. 4. 543-567.

GAzDA István: A Magyar Tudós Társaság elveszettnek hitt 1848-as magyar nyelvtankönyvei $=$ Alexander multifrons... 161-167. ill.

TöRöK József: Pannonhalma és a patrisztikus irodalom $=$ Episcopus, archiabbas benedictinus, historicus ecclesiae... 47-54.

\section{9-20. század}

KnApP Éva: Ágoston Péter Martin von Cochem fordításának utóéletéhez $=$ In via eruditionis... 160-171

Knapp Éva: Ágoston Péter Mennyei követek (1681) fordításának kiadástörténeti utóéletéhez, 1845-1911 = MKsz (132.) 2016. 2. 133-145.

TÜsKÉs Gábor: A Confessio peccatoris kiadásés fordítástörténetéhez $=$ In via eruditionis... 138-148. 
20. század

PogÁnY György: Az Egyetemi Nyomda ifjúsági kiadványai a két világháború közötti években $=$ KN (18.) 2016. 2. 51-70.

Püski Sándor élete hagyatékának tükrében / PÜSKI István, Gulay István. Bp.: Püski, 2015-2016. $3 \mathrm{db}$ ill.

3. „Magyar ügyben mindenkivel szóba állunk". 1970-2009. 2016. 397 p.

SzEREdi Pál: Püski Sándor. Politikai életrajz. Pilisszentkereszt: Barangoló K., 2016. 230 p.

\section{Sajtótörténet}

\section{Több évszázadot érintő munkák}

BuZINKAY Géza: A magyar sajtó és újságírás története a kezdetektől a rendszerváltásig. Bp.: Wolters Kluwer, 2016. 548 p.

\section{8. század}

ECSEDY Judit, V.: Egy meghiúsult újságról = Alexander multifrons... 143-150. ill.

A Függelékben a vonatkozó dokumentumok listájával és források szövegközlésével

\section{8-19. század}

Antal Alexandra: A Bécsi Magyar Hírmondó (1789-1803) és Kisfaludy Sándor $=$ A két Kisfaludy. Tanulmányok / szerk. HANSÁGI Ágnes, Hermann Zoltán. Balatonfüred: Balatonfüred Városért Közalapítvány, 2016. 11-18.

\section{9. század}

ABonYI Magdolna: A magyar rendőri szaksajtó kezdetei. A Közbiztonság = Magyar Rendészet (16.) 2016. 6. 155-168.

BAcsó Vivien: Egy vidéki női lap és munkatársai az 1800-as években = Publicationes Universitatis Miskolciensis. Sectio philosophica. (19.) 2015. 7-23. ill.
Bódy-Márkus Rozália: Die Geschichte der deutschsprachigen Presse in Ungarn.Ein Forschungsgebiet im Schnittpunkt mehrerer Disziplinen $=$ Az Eszterházy Károly Főiskola tudományos közleményei. Germanistische Studien. (10.) 2016. 67-75.

GÁBori KovÁcs József: A centralista Pesti Hirlap politikai stratégiái, 1844-1847. Bp.: Argumentum K., 2016. 374 p. (Irodalomtörténeti füzetek; 176.)

BARnA Béla: A rendszeres egri sajtó indulása. Az Egri Értesító és az Egri Posta (1860$1863)=($ Magyar) nemzet és Európa. Tanulmányok a 70 éves Martin József tiszteletére / szerk. Széchenyi Ágnes, BuzinKay Géza. Eger: Líceum K., 2014. 17-36. ill.

BARnA Béla: Az Eger és Vidéke hetilap (18841893 ) és újságírói $=$ PhD-hallgatók III. Konferenciája. 2014. május 16. / szerk. RAKITA Eszter. Eger: EKF Líceum K., 2015. 22-42.

HÁsz-FeHÉr Katalin: A sajtótér dominanciájának kérdése Kazinczy és Kisfaludy Sándor vitáiban. Egy kiegészítés Füredi Vida 1818as értekezésének értelmezéséhez $=$ ItK (120.) 2016. 4. 419-446.

Kocsis Lajos: A kézdivásárhelyi Székely Közlöny „változatos pályafutása” (1879-1881) = MKsz (132.) 2016. 2. 215-220.

RózsA Mária: Átvételek, kapcsolódások, közös munkatársak reformkori pesti és bécsi szépirodalmi lapokban $=$ MKsz (132.) 2016. 2. 146-156. ill.

Sımon Bernadett: Egy kiállítás képei = Nézőpontok. Tanulmányok / főszerk. ERDŐDY Gábor; szerk. Pettinger-Szalma Vendel, Sós János. Bp.: ELTE Történelemtud. Doktori Isk., 2016. 27-40.

Az Eötvös Loránd Tudományegyetem Bölcsészettudományi Kar Történelemtudományok Doktori Program konferenciáján Budapesten 2015. június 2-án elhangzott előadás kiegészített, szerkesztett változata

То́тн Benedek: Heti csevegés a Bécsi Hiradóban. Náday Ezüstös (Ágai Adolf) 1865-ös tárcasorozata mint a Wochenplauderei egyik első magyar nyelvủ példája = (Magyar) nemzet és Európa. Tanulmányok a 70 éves 
Martin József tiszteletére / szerk. SzÉCHENYI Ágnes, BuzinKay Géza. Eger: Líceum K., 2014. 279-294.

UjvÁRI Hedvig: Mit olvashatott Bismarck Jókaitól? Jókai regényei németül Pest-Budán és Berlinben (Magyar) nemzet és Európa. Tanulmányok a 70 éves Martin József tiszteletére / szerk. SzÉCHENYI Ágnes, BuZINKAY Géza. Eger: Líceum K., 2014. 295-304.

\section{9-20. század}

KLestenitz Tibor: Die Presse als Mittel des politischen Katholizismus in Ungarn $=$ Kritische Zeiten. Zeitschrift für Humanwissenschaften (7.) 2016. 1-2. 1-17.

MAKKAI Béla: Határon túli magyar sajtó Trianon előtt. Bukaresti és eszéki magyar lapok az identitásőrzés és kisebbségi érdekvédelem szolgálatában, 1860-1918. Bp.: Médiatud. Int., 2016. 209 p. (Médiatudományi könyvtár; 23.)

Miklós Péter: A Kecskeméti Lapok története, 1868-1956. Szeged: Bálint S. Szellemi Örökségéért Alapítvány, 2016. 132 p. ill.

PAP Dávid Zoltán: „A betüvel szemben betüt állítsatok" A pécsi katolikus újságírás kezdetei : a Pécsi Közlöny (1893-1903) = Történetek Baranyából... 9-117.

\section{0. század}

BALLA Tibor: Az osztrák-magyar Sajtóhadiszállás szervezete és tevékenysége a Nagy Háborúban $=$ Propaganda. Politika, hétköznapi és magas kultúra, müvészet és média a nagy háborúban... 273-286.

BAUMGARTNER Bernadette: Források a Látóhatár alapításának történetéhez $=$ Sed intelligere. Tanulmányok a hatvanöt éves Gyarmati György tiszteletére / szerk. SLAchta Krisztina, BÁnkuti Gábor, VonYó József. Pécs: Kronosz, 2016. 297-310.

BENGI László: Az irodalom színterei. Irodalom és sajtó összefüggésrendszere a 20. század első évtizedeiben. Bp.: Ráció K., 2016. 207 p. (Ráció-tudomány; 24.)
A Budapesti Újságírók Egyesülete 1909-ik évi almanachja / szerk. SzERDAHELYI Sándor; kísérő tanulmány BoKa László, SzÉNÁSI Zoltán. Repr. kiad. Bp.: OSZK-Argumentum K., 2016. ill.

Egy alkalommal jelent meg; Az eredeti kiadás megjelenési adatai: Bp.: Budapesti Újságírók Egyesülete, 1909

BuZINKAY Géza: Sajtó és/vagy propaganda az első világháború alatt $=$ Propaganda. Politika, hétköznapi és magas kultúra, múvészet és média a nagy háborúban... 231-246. ill.

FLeIsz János: Az erdélyi kisvárosok és községek sajtója 1900 és 1940 között = Vidéki élet és vidéki társadalom Magyarországon. A Hajnal István Kör - Társadalomtörténeti Egyesület 2014. évi, egri konferenciájának kötete / szerk. PAP József, TóтH Árpád. Bp.: Hajnal I. Kör Társadalomtört. Egyes., 2016. 165-181. 640-641.

FLEISZ János: Az erdélyi magyar sajtó története, 1940-1944. Pécs: Pro Pannonia, 2016. 279 p. ill. (Pannónia könyvek)

FARKAS László: Deres március. Az Új Írás születése és első esztendei. Bp.: Anonymus, 2016. 197 p. ill.

KeREKES Imre: A Pécsi Katolikus Tudósító (19211944) = Történetek Baranyából... 118-130.

A szerző a MKSz 2002/2. számában megjelent tanulmányának bővített változata

MoLnÁR Sándor Károly: Házi Istentisztelet: avagy egy kegyességi lap tiszavirágú története $=$ Natio est semper reformanda... 282-292.

NÉMETH László: Új úton. A református sajtó és reformátusok sajtóban az 1956-os forradalom és szabadságharc idején $=$ A család és a közösség szolgálatában. Tanulmányok Komlósi Piroska tiszteletére / szerk. SpannRafT Marcellina, Korpics Márta, NéMETH László. Bp.: KRE-L'Harmattan, 2016. 155-168.

RóBERT Péter: Célegyenesben: siker és betiltás. A cionista sajtó története Magyarországon, 1947-1949. Bp.: Mo. Cionista Szövets. - Bethlen Téri Oneg Sábbát Klub, 2016. 287 p. ill. (Bethlen téri füzetek)

SCHMElCZER-PoHÁNKa Éva: Hallgatói periodikumok a pécsi Magyar Királyi Erzsébet Tu- 
dományegyetemen. A Maurinum, melléklapja a Móric(zka) és a Pécsi Jogász $=$ MKsz (132.) 2016. 2.185-208 ill.

SzEREDI Pál: A Látóhatár szerkesztőségi ellentétének háttere 1957-1958-ban. 2. rész Magyar Szle (25.) 2016. 1-2. 62-70.

SzIGETI Lajos: A lazarista sajtó a két világháború között és a második világháború alatt Magyarországon $=$,Evangelizare pauperibus misit me!" Lazaristák Magyarországon / szerk. Csíky Balázs, ILlés Pál Attila. Bp.: METEM- Historia Ecclesiastica Hungarica Alapítvány; Piliscsaba: PPKE BTK, 2016. 121-134. ill.

SzŐTs Zoltán Oszkár: Katonai tábori újságok az első világháborúban - 16-os Honvéd, Négyes Honvédek Háborús Lapja, Cibo Viccek $=$ Az első világháború információtörténetéhez / szerk. Z. Karvalics László. Bp.: Gondolat, 2016. 323-336.

TvERDOTA György: József Attila Szerkesztői üzenete $=$ Literatura (42.) 2016. 3. 149-166.

\section{Sajtótermékek mint forrásanyagok}

BALÁzs Eszter: Értelmiségellenesség az első világháború első felében. „Kávéházi stratégák” és „lógós” írók Budapesten = Értelmiségi karriertörténetek 2. / szerk. Bíró Annamária, Boka László. Nagyvárad: Partium K; Bp.: Reciti, 2016 153-179.

BÁRÁNY Zsófia: A religio és a nemzet elválaszthatatlansága. A bencés rend szerepe a modern Magyarország kialakulásában $=$ Collectanea Sancti Martini. (4.) 2016. 119-131.

Csíky Balázs: 1938 szimbolikus eseményei a magyarországi zsidó sajtó tükrében = Egyháztört. Szle (17.) 2016. 2. 60-78.

Csonki Árpád: Kánya Emília Családi Körének nőképe az írónő-vita idején = Publicationes Universitatis Miskolciensis. Sectio philosophica. (19.) 2015. 1. 69-91.

A tanulmányt tartalmazó kötet az impreszszumadatok alapján 2016-ban jelent meg.

Csunderlik Péter: Lukács György és a Szabadgondolat bolsevizmus-vitája $=$ A forradalom végtelensége. Lukács György politi- ka- és társadalomelmélete / szerk. BöCSKEI Balázs. Bp.: L'Harmattan, 2016. 65-81. 242. Diószegi SzABó Pál: „A szomszédban... hát ez szocializmus?" Tömörkény István tudósítása Szántó-Kovács János peréről, 1895 márciusában $=$ Tömörkény 150 . Tanulmányok a 150 éve született Tömörkény István tiszteletére / szerk. BENE Zoltán. Szeged: Areión Kv., 2016. 182-312. ill.

Dukkon Ágnes: Frölich Dávid humora. Időjóslási kommentárok az 1641-ben Nürnbergben kiadott kalendáriumában $=$ Monokgraphia... 163-169. ill.

Fenyvesi Katalin: Párhuzamos lojalitások. Császárhüség, magyar nemzeti és zsidó elkötelezettség a magyarországi zsidó nyilvánosságban = „A királyhűség jól bevált útján..."... 133-146. ill.

GLÄSSER Norbert: A messiási kor előjelei? Az antiszemitizmus vallási értelmezései a két világháború közötti budapesti orthodox zsidó sajtóban = Emlékeztető (1.) 2016. 3-4. 14-20.

GLÄSSER Norbert: Az isteni dicsőség visszatükröződései. A koronás fő izraelita értelmezései $=$ „A királyhüség jól bevált útján...”... 405-422. ill.

HaRmati Róbert: Pénzhamisításról szóló hírek az Országos Hírlap címü napilapban Valóság (59.) 2016. 8. 71-76.

HóвоR József: Elvek, eszmék, egyház. Adalékok Pehm (Mindszenty) József zalaegerszegi müködésének első évtizedeihez. Nagykanizsa: Czupi, 2016. 259.

Sajtóra vonatkozó adalékokkal

Huszár Zoltán: A Pesti Hírlap és Baranya megye, 1841-1844 [elektronikus dok.] = Tudásmenedzsment (17.) 2016. 1. 48-62.

A tanulmány a szerző Cikkek, reflexiók a Dél-Dunántúlról a Pesti Hírlapban (18411844) c. dolgozatának Baranya megyére vonatkozó része

HusZÁr Zoltán: Cikkek, reflexiók Dél-Dunántúlról a Pesti Hírlapban (1841-1844) = Történetek Baranyából... 43-65.

JAKAB Attila: A magyarországi keresztény média a zsidótörvények idején (1938-1942) = Tanulmányok a holokausztról / szerk. Ran- 
dolph L. Braham. Bp.: Balassi, 2001-2016. 13-108.

Katona Anikó: Háborús plakát. Hatásos fegyver vagy patrióta giccs? A háborús (plakát) művészet korabeli megítélése, a német Das Plakat cikkeiből kiindulva = Propaganda. Politika, hétköznapi és magas kultúra, mủvészet és média a nagy háborúban... 491-516. ill.

KePPEL Csilla: Hadisebesültek görbe tükörben.

Bořivoj Rambousek első világháborús karikatúrái. Szombathely: Smidt Múz.-Savaria M. Hatókörü Vár. Múz., 2016. 111 p. ill. Szombathely első világháborús történetéhez

KLestenitz Tibor: Nagy-Britannia képe a központi hatalmak propagandájában a háború első éveiben = Jel-kép 2016. 1. 62-70.

KLestenitz Tibor: A katolikus nagygyülések, mint médiaesemények az 1920-as években = Magyar Egyháztört. Vázlatok. (27.) 2015. $1-2.57-75$.

KLESTEnITZ Tibor: A Nagy Háború propagandájának megítélése a magyar sajtóban $=$ Propaganda. Politika, hétköznapi és magas kultúra, müvészet és média a nagy háborúban... 287-301.

KLESTEnITz Tibor: Tisza István alakja a karikatúrák tükrében $=$ Tisza István, két korszak határán / szerk. IFJ. BERTÉNYI Iván. Bp.: Országgyülés Hiv. 2016. 177-200.

KovÁcs Csaba: A „Délvidék” és a „Vajdaság” 1941-1948 között a sajtó és az emlékezet tükrében = Magyarok és szerbek a változó határ két oldalán, 1941-1948. Történelem és emlékezet / szerk. HoRnYÁk Árpád, Bíró László. Bp.: MTA BTK TTI, 2016. 129-158.

LÁszló Gábor (IFJ.): Állam, egyház és szabadság a szekularizáció baptista koncepciójában a Horthy-korszakban = Habitus. Tanulmányok a Colloquium Officiale II konferencia elöadásaiból / szerk. BARÁtH Dóra, KIss Alpár. Bp.: Mika S. Egyes., 2016. 237-270.

Ligeti Dávid: A visegrádi remete utolsó útja. Görgei Artúr halálának társadalmi visszhangja 1916-ban $=$ Natio est semper reformanda... 409-416.
MikLós Péter: A revíziós gondolat és a területgyarapodás a „Kecskeméti Lapok” hasábjain = KEK (9. ) 2016. 4. 166-171.

Mózessy Gergely: „Állítólag Prohászka egyszer..." = Episcopus, archiabbas benedictinus, historicus... 381-392.

NAGYi Enikő Orsolya: A dési sajtó antitszemitizmusa és antiszemitái (1940-1944) = Tanulmányok a holokausztról / szerk. Randolph L. Braham. Bp.: Balassi, 2001-2016. 109-137.

NAGYMIHÁLY Zoltán: Emigrációs Látóhatár. Szemelvények az 1950-es évek magyar emigrációs közgondolkodásából = Társadalom térben és időben. Tanulmányok az új- és modernkori Magyarország eszme-, mủvelödésés társadalomtörténetéről / szerk. SzuLY Rita, KRÁnItz Péter Pál. Bp.; Piliscsaba: M. Napló - Írott Szó Alapítvány, 2015. 207-217.

NÉMETH Ferenc: Élet a Bánátban a német megszállás alatt, 1941-1944. A mindennapok és a magyarságtudat alakulása a Torontál címü lap tükrében = Magyarok és szerbek a változó határ két oldalán, 1941-1948. Történelem és emlékezet / szerk. HoRnYÁK Árpád, Bíró László. Bp.: MTA BTK TTI, 2016. 177-205.

RózsA Mária: Adalékok Jósika Miklós 1848 elötti regényeinek fogadtatásához az egykorú német nyelvü sajtóban = ItK (120.) 2016. 2. 207-214.

SÁrai SzABó Katalin: „A szép Haverda Mariska, a lovag és a gavallér" Egy szabadkai anyagyilkosság reprezentációi = Médiakutató (16.) 2016. 3-4. 171-192.

Somogy László: Szerb ellenségkép Magyarországon az első világháború alatt a sajtó tükrében. = Jel-kép 2016. 1. 61-70.

SzABó Dániel: A magyarországi sajtó a háború kitörésekor $=$ Propaganda. Politika, hétköznapi és magas kultúra, múvészet és média a nagy háborúban... 247-256.

Szabó Dóra Éva: Várkonyi Hildebrand Dezső fö gondolatai a Cselekvés iskolája címü folyóirat tükrében $=$ Gutta cavat lapidem. Az esőcsepp kivájja a követ. Hallgatói tanulmányok a neveléstörténet tárgyköréböl. A Kiss Áron Neveléstörténeti Tehetség- 
mühely publikációi / szerk. Fizel Natasa. Szeged: Délvidék Kut. Közp. Alapítvány, 2016. 26-39.

SzABó Előd: „Jelentésem és egyúttal szolgálatom végére érkeztem". Győry Elemér püspökségének utolsó évei hivatalos folyóirataink tükrében $=$ Felelet a Mondolatra. Tanulmányok a 60 éves Bogárdi Szabó István tiszteletére / szerk. ZsEngelLér József, KodÁcsy Tamás, ABLonczy Tamás. Bp.: KREL'Harmattan; Pápa: PRTA, 2016. 395-402.

SzABÓ-RezneK Eszter: Meltzl Hugó és a kolozsvári Petőfi-ellenkánon: kísérlet a „nemzeti költő" regionális újraértelmezésére = ItK (120.) 2016. 2. 215-224.

SzÉKELY Tamás: A szövetséges uralkodók kultusza Magyarországon az első világháborúban = Propaganda. Politika, hétköznapi és magas kultúra, múvészet és média a nagy háborúban... 87-103.

SzIKSZAI Gergely: Katolikus papság és egyetemista ifjúság az antiszemitizmus szolgálatában a 12 röpirat tükrében $=$ Nézőpontok. Tanulmányok / föszerk. ERDÖDY Gábor; szerk. Pettinger-Szalma Vendel, Sós János. Bp.: ELTE Történelemtud. Doktori Isk., 2016. $11-26$.

Az Eötvös Loránd Tudományegyetem Bölcsészettudományi Kar Történelemtudományok Doktori Program konferenciáján Budapesten 2015. június 2-án elhangzott előadás kiegészített, szerkesztett változata

SzÖTs Zoltán Oszkár: Egy kultusz kezdetei. A limanovai csata megjelenése a napilapokban = Jel-kép 2016. 1. 25-30.

TAMÁs Ágnes: „Monsieur János, valójában mit akar? Különben is, a glóbuszát meghagytam Önnek!” Területveszteségek és gyarapodások élclapok karikatúráin (1919-1921) = Aetas (31.) 2016. 2. Törésvonalak. 52-69. ill.

TAMÁs Ágnes: Háborús hétköznapok a Borsszem Jankó rajzainak tükrében. A Borsszem Jankó életképei $=$ Háborús hétköznapok. Tanulmánykötet / szerk. TöRÖK Róbert, ZÁvODI Szilvia. Bp.: MKVM, 2016. 203-216. ill.

TAMÁs Ágnes: A Párizs környéki békék kritikája élclapok karikatúráin (1919-1921) = A humor nagyítón keresztül / szerk. BODA-UJLAKY
Judit et al. Bp.: Tinta Kvk.- Selye J. E.ELTE BTK, 2016. 71-79.

TAMÁs Ágnes: A nagy háború a Borsszem Jankó karikatúráin. Alkotók és alkotások a propaganda hálójában = Jel-kép 2016. 1. 31-47.

TAMÁs Ágnes: Ellenségképek és önkép jugoszláv és magyar karikatúrákon (1945-1947) = Létünk 2016. 4. 139-153.

TAMÁs Ágnes: A tiszaeszlári vérvád és a nyíregyházi per az élclapok hasábjain $=$ MKsz (132.) 2016. 2. 157-184. ill.

TöтTős Gábor: A Perczelekkel kapcsolatos humor a sajtóban. 1848-1882 = Források a Völgység tanulmányozásához. Előadások a VI. Völgységi Konferencián. 2015. október 30. / szerk. SzŐTs Zoltán. Bonyhád: Völgységi Múz., 2016. 107-116. ill.

Elhangzott előadás (Bonyhád, 2015) szerkesztett változata.

ÜvEgES Bence: Találkozik-e Freud Grünnel? Magyarországi zsidó humorérzékek 1868-1925 = Vidéki élet és vidéki társadalom Magyarországon. A Hajnal István Kör - Társadalomtörténeti Egyesület 2014. évi, egri konferenciájának kötete / szerk. PAP József, TóтH Árpád. Bp.: Hajnal I. Kör Társadalomtört. Egyes., 2016. 128-136., 639.

VÉR Eszter Virág: A hivatalos képalkotás „alternatívái”. Az uralkodópár (privát) életeseményeinek megjelenítése az 1850-es évek magyar nyelvű sajtójában $=$ Natio est semper reformanda... 199-209.

ZIMA András: Dinasztikus hűség egy dinasztianélküli korban $=$,A királyhüség jól bevált útján..." ... 445-456. ill.

\section{Könyvtártörténet}

\section{Több évszázadot érintő munkák}

BAKonyi Gábor-Bakonyi Zsuzsanna: A Pannonhalmi Főapátsági Könyvtár zoológiai könyvei a 16-18. századból = MKsz (132.) 2016. 4. 463-478. ill.

BALOGH Mihály-KIsARI Ottilia: Fejezetek a kunszentmiklósi református gimnáziumi könyvtár történetéből. A huszonöt éves Pro Bib- 
liotheca Antiqua Baksayana Alapítvány Bp.: Mo. Református Egyh. Zsinati Hiv.; Šamorín: Méry Ratio, 2016. 149 p. ill.

Bibliotheken, Dekor. 17-19. Jahrhundert / hrsg. von Frédéric BARBIER, István MonOK, Andrea De Pasquale. Bp.: Bibl. der Ungarischen Akad. der Wiss.; Roma: Bibl. Nazionale Centrale di Roma - Éd. des Cendres, 2016. 306 p. ill.

Váltakozva francia, német és olasz nyelven Cordea Márta: A Szatmár Megyei Könyvtár kincsei $=$ Certamen III. Előadások a Magyar Tudomány Napján az Erdélyi MúzeumEgyesület I. szakosztályában. Nyelv-, irodalom- néprajztudomány történelem / szerk. Egyed Emese, PAKó László. Kolozsvár: Erdélyi Múzeum-Egyes. 2016. 201-208.

Gordán Edina: Gondolatok egy könyvtárról. A Bethlen Gábor Dokumentációs Könyvtár története $=$ A nagyenyedi fönixmadár. Adalékok a Bethlen Gábor Kollégium történetéhez. Szerk. Kapitány-Horváth Zsuzsa. Nagyenyed: Bethlen Gábor Alapítvány, 2016. 65-76. ill.

\section{5. század}

KNAPP Éva: Nevezetes ősnyomtatványok az ELTE Egyetemi Könyvtárban = KKK (25.) 2016. 2. 29-32.

\section{5-16. század}

LuPEscuné MaKó Mária: Domonkos könyvkultúra Erdélyben = Testimonio litterarum... 233-250.

18. század

FaA-Lendvai Erzsébet: Bencés könyvtárak a 18. századi Magyarországon = Történelem és Muzeológia ( 3.) 2016. 1. 100-110.

KNAPP Éva: Egy ismeretlen mariánus ferences könyvtár a 18. században = Monokgraphia... 385-404.

RÁcz Emese: Benkő József nagyenyedi hungarika könyvjegyzéke = MKsz (132.) 2016. 3. 284-297.
Schmelczer-Pohánka Éva: „Mennyire szép odabent! Mily nagy a hírneve kint!” A pécsi püspöki bibliotéka alapításának korabeli ismertetései és recepciói $=$ „Új könyvtár virul itt, tele rendbe rakott tudománnyal. Fontos, hogy mindent nyitva találsz odabent.”... 25-46. ill.

\section{9. század}

PÁKozdi Éva Szilvia: A veszprémi piarista könyvtárak adományozói 3. Dr. Láncz Nándor, orvos $=$ Veszprémi Szle (18.) 2016. 3. 4660. ill.

\section{9-20. század}

ÁbrahÁm Vera: A Löw Könyvtár sorsa. Mit mondanak a megmaradt iratok? 1. rész. Szeged: Dr. Birnfeld S. Kvt., 2016. 54 p. ill. (Könyvtári tudományos füzetek; 1.)

GyuriczA Andrea: A Nemzeti Casino = KF (26.) 2016. 1. 59-69.

A Magyar Tudományos Akadémia Könyvtárába bekerült egyesületi könyvtár állományának múltja és jelene

KAPRONCZAY Katalin-Magyar László András: A Semmelweis Orvostörténeti Könyvtár gyüjteményének története $=$ Per aspera ad astra. (3.) 2016. 1. 69-79.

\section{0. század}

BUDAI László: A várpalotai városi könyvtár létrejöttének közvetlen elözményei, 1949-1954 $=\mathrm{KKK}$ (25.) 2016. 2. 33-37.

Gracza Tünde: Possessorok nyomában. A Tóth Lajos Könyvtár állományát lapozgatva... = Orvosi könyvtárak (13.) 2016. Klsz. Jubileumi tanulmányok. A Pécsi Tudományegyetem Egyetemi Könyvtár és Tudásközpont Pekár Mihály Orvosi és Élettudományi Szakkönyvtár alapításának 90. évfordulójára. 32-47.

Elhangzott a 2016. szept. 30-án megrendezett emlékülésen

SCHMELCZER-PoHÁNKA Éva: A Tóth Lajos Könyvtár és az orvoskar intézeti és klinikai könyvgyüj- 
teményei az Erzsébet Tudományegyetem időszakában = Orvosi könyvtárak. (13.) 2016. Klsz. Jubileumi tanulmányok. A Pécsi Tudományegyetem Egyetemi Könyvtár és Tudásközpont Pekár Mihály Orvosi és Élettudományi Szakkönyvtár alapításának 90. évfordulójára. 24-31. ill.

Elhangzott a 2016. szept. 30-án megrendezett emlékülésen

KÉGLI Ferenc: Adalékok könyvtárügyünk homályos éveiről, 1945-1949. Az Országos Könyvtári Központ első évei és a körzeti könyvtárak szervezése $=$ KF (26.) 2016. 1. 34-50. „A magyarországi könyvtárügy története a Rákosi-korszakban 1945-1956" kutatási program keretében született résztanulmány.

Szeberényi Gábor: Holub József és a Tagányi-könyvtár Pécsre kerülése. Egy ,vidéki” történészprofesszori egzisztencia lehetőségfeltételei az 1920-as évek elején. 3. befejező közlemény $=$ Per aspera ad astra (3.) 2016. 1. 92-107.

VIRÁGOS Márta: A Simonffy utcától az Egyetem térig. Az Egyetemi Könyvtár első évtizedei = Gerundium (7.) 2016. 3-4. 100-113.

\section{Bibliofilia, magánkönyvtárak}

BíRó-Balogh Tamás: Pár újabb kötet Tömörkény könyvtárából $=$ Tömörkény 150 . Tanulmányok a 150 éve született Tömörkény István tiszteletére / szerk. BENE Zoltán. Szeged: Areión Kv., 2016. 65-91.

Bíró Gyöngyi: ,... non contemnenda librorum...” Enyedi György könyvtárának kutatása. = Enyedi 460. Tanulmánykötet Enyedi György születésének 460. évfordulójára rendezett kamarakonferencia előadásaiból / szerk. K. KAPOSI Krisztina, LovAs Borbála. Bp.: MTAELTE HECE, 2016. 11-26. ill.

BujtÁs László Zsigmond: Egy elfeledett 18. századi erdélyi főuri könyvtár nyomában. Kendeffi Elek hollandiai könyvvásárlásai (17611762) = Monokgraphia... 102-108.

Collectors and collections. The Treasures of the Collections in the National Széchényi Library and the Histories of the Collections
/ ed. by László Boka, Lídia Wendelin FeRENCZY; transl. Thomas CoOPER; Bp.: Nat. Széchényi Library-Kossuth, 2016. 252 p. ill. A Gyüjtők és gyüjtemények c. kötet (2009) tanulmányai angol nyelven

Csukovits Enikő: Geográfiai ismeretek két korszak határán. Hans Dernschwam könyvtárának geográfiai tárgyú kötetei $=$ Müvészet és mesterség. Tisztelgő kötet R. Várkonyi Ágnes emlékére / szerk. Horn Ildikó et al. Bp.: L'Harmattan, 2016. 149-159.

FARKAS Judit Antónia: Szana Tamás és a modern magyar bibliofília $=$ Natio est semper reformanda... 260-271.

FAZEKAS István: Egy könyvjegyzék tanulságai. Heresinczy Péter győri püspök, kancellár és a hagyatékában összeírt könyvek (1590) = Monokgraphia... 195-201.

FreY György Péter: Gewölbebau im Barock in der Klimo Bibliothek vorliegende architektonische Fachliteratur und deren praktische Anwendung im Kirchenbau = Hegyen épült város... 239-247. ill.

GranaszTói Olga: Litteris in Patria Augendis? Könyvtártörténeti elmélkedések a „másik” Apponyi könyvtár sorsának apropóján. 1774 2011 = Monokgraphia... 220-227.

Hencz Enikő: Mit ajánlhatott Dobai Székely Sámuel Klimo György pécsi püspöknek? Dobai Székely Sámuel könyvtárának kínálata $=$ „Új könyvtár virul itt, tele rendbe rakott tudománnyal. Fontos, hogy mindent nyitva találsz odabent." ... 267-276.

HoRvÁth Mária, M.: Pázmány Péter magánkönyvtárának újabban azonosított kötetei = Egyház és reprezentáció a régi Magyarországon... 267-272.

Horváth Mária, M.: Pázmány Péter pozsonyi magánkönyvtárának újabb tizenhárom kötete $=$ MKsz (132.) 2016. 4. 479-489. ill.

KnAPp Éva-Tüskés Gábor: II. Rákóczi Ferenc rodostói könyvtárának új rekonstrukciós kísérlete $=$ A felvilágosodás előzményei Erdélyben és Magyarországon, 1650-1750 / szerk. Balázs Mihály, BARTóк István. Szeged: SZTE M. Irodalmi Tanszék, 2016. 227-247. A függelékben a rekonstruált könyvgyüjtemény 234-247. 
KovÁcs Teofil: „Le rajzoltam a magam tékámat...". Szilágyi Sámuel könyvszekrényleírása 1740-ből = MKsz (132.) 2016. 3. 368-371.

Szilágyi Sámuel levelének szövegközlésével

KRÁsz Lilla: Bibliofil föurak. Festetics György gróf orvostudományi könyvgyüjteményéről. Vázlat = Monokgraphia... 425-434.

Mıкó Árpád: Ötvösművek, vésett ékkövek, könyvek Sebastiano da Lugo, Ippolito d'Este esztergomi érsek praeceptorának hagyatékában. (Esztergom, 1490) = Folia Historica. (31.) 2015. $\{2016\}$. 9-15.

Mizera Tamás: Könyv és mesterség a kora újkori Magyarországon. A magánkönyvtárképződés tendenciái a polgárság körében, különös tekintettel a tanítók gyüjteményeire = Szöveg, hordozó, közösség. Olvasóközönség és közösségi olvasmányok a régi magyar irodalomban. Fiatalok Konferenciája 2015 / szerk. GeszTelyi Hermina, GöRÖG Dániel, Maróthy Szilvia. Bp.: Reciti, 2016. 229-243. ill., http://reciti.hu/2016/ 3826

MonoK István: Rákóczi Zsigmond fejedelem Schedel-krónikája = Testimonio litterarum... 279- 284.

MoRITz Kinga: Körmöczi János könyvtárának feltárása = Certamen III. Előadások a Magyar Tudomány Napján az Erdélyi Múzeum-Egyesület I. szakosztályában. Nyelv-, irodalomnéprajztudomány történelem / szerk. EGYED Emese, PAKÓ László. Kolozsvár: Erdélyi Múzeum-Egyes., 2016. 181-189.

NAGY Györgyi: The Reception of the Battle of Buda (1686) in the Light of the Apponyi Hungarica Collection $=$ Kniha (Martin, Slovenská Národná Kniznica) 2016. 47-54. ill.

OLÁH Róbert: Szenci Molnár Albert ajándék Institutiója Budai Péternek = In via eruditionis... 252-259.

ORLovszKy Géza: Az Istvánffy-könyvtár egy kötete a Pálos Könyvtárban = Monokgraphia... 527-532. ill.

TÚRI Klaudia: Calendars in the TodoreszkuCollection = Kniha (Martin, Slovenská Národná Kniznica) 2016. 66-71. ill.
VARGa Bernadett: Három kötet Vitnyédy István elveszett könyvtárából = MKsz (132.) 2016. 1. 81-88.

VISKolcz Noémi: The Fate of Johannes Sambucus'Library = Hungarian Studies (30.) 2016. 2. 155-166.

VIskolcz Noémi: Zsámboky János könyvtárának sorsa $=$ MKsz (132.) 2016. 4. 404-444.

VIskolcz Noémi: A Bibliotheca Windhagiana. Egy különleges arisztokrata könyvtár a 17. századból = Monokgraphia... 745-749.

Zvara Edina: Egy tudós hazafi Bécsben. Görög Demeter és könyvtára. Bp.: OSZK-Gondolat, 2016. 506 p.: ill. (Nemzeti téka)

\section{Olvasástörténet}

BALÁzs Mihály: Szent vagy profán? Adalék Sebastian Castellio erdélyi recepciójához $=$ In via eruditionis... 106-114.

BALÁzs Mihály: A Zrínyi-könyvtár három tételéről. (Könyvjegyzékmérgezés ellen való orvosság) = Monokgraphia... 47-50.

BALOG Edit Otilia: Az Uránia célközönsége - szándék és valóság = Szöveg, hordozó, közösség. Olvasóközönség és közösségi olvasmányok a régi magyar irodalomban. Fiatalok Konferenciája 2015 / szerk. Gesztelyi Hermina, Görög Dániel, MARÓthy Szilvia. Bp.: Reciti, 2016. 11-20. http://reciti.hu/2016/3826

Bene Sándor: A sztoikus Zrínyi = Monokgraphia... 69-86.

Bíró Csilla: The Work entitled Seneca Christianus Among the Editions of the Congregation of Visitation of Our Lady at Trnava = Kniha (Martin, Slovenská Národná Kniznica) 2016. 40-46.

Csorba Dávid: A kapitiha Bibliája (1679) = Egyháztört. Szle (17.) 2016. 1. 108-111.

Csorba Dávid: Gyöngyösi Árva Pál tudóskodó verses gúnyirata $=$ Egyháztört. Szle (17.) 2016. 2. 111-113.

Csorba Dávid: Gyöngyösi Pál angliai könyve = Egyháztört. Szle (17.) 2016. 4. 127-129.

Csorba Dávid: „Szemeimmel láttam” - Sajószentpéteri István kálvinista prédikátor látens forrásai $=$ In via eruditionis... 342-353. 
Csorba Dávid: Egy Pázmány-Kalauz dühödt olvasóinak teológiai, tropológiai és stílusparódiái = Útmutató... 71-97. ill.

FAA-LendVAi Erzsébet: A tihanyi bencések és olvasmányaik a 18 . század végén $=$ Doktorandusz Hallgatók IV. Konferenciája. 2015. május 14. / szerk. FÁBIÁN Máté. Eger: EKF Líceum K., 2016. 41-58.

Font Zsuzsa: A spiritualizmus és a radikális pietizmus irodalma Szebenben. Andreas Teutsch könyvei a Brukenthal-gyüjteményben $=$ Monokgraphia... 209-213.

Hegyi Ádám: Samuel Werenfels (1657-1740) szerepe a magyarországi felekezeti szembenállások csökkentésében a 18. században = A felvilágosodás előzményei Erdélyben és Magyarországon, 1650-1750 / szerk. BALÁzs Mihály, BARTóK István. Szeged: SZTE M. Irodalmi Tanszék, 2016. 303-314.

Hegyi Ádám: Fábián János békési református tanító veszedelmes könyvei $=$ Monokgraphia... 260-267.

IGAZ Levente: Brazília és a brazíliai emigráció a két világháború közötti magyar olvasóközönség szemével = Hidak és áthallások. Tanulmányok a brazil-magyar kapcsolatok köréből / szerk. PÁl Ferenc; Az ELTE Brazil Tudományos Központjának kiadása. Bp.: ELTE Eötvös K., 2016. 25-41.

KIss Gábor: A 19-20. század kánonjogi műveltsége Pécsett $=$ „Új könyvtár virul itt, tele rendbe rakott tudománnyal. Fontos, hogy mindent nyitva találsz odabent."... 149-162. ill.

KNAPP Éva: Egy 18. századi mariánus ferences könyvtár. Mesztegnyő, 1748-1790. = Magyar Egyháztört.Vázlatok (27.) 2015. 1-2. 19-46.

KRISTÓF Ildikó, Sz.: „Indi legendi \&scribendi usum mirantur". Egy kulturális sztereotípia múltjáról és régi magyarországi előfordulásáról = Monokgraphia... 435-446.

LABÁDI Gergely: A pikareszk Magyarországon a 18-19. század fordulóján = ItK (120.) 2016. 2. 178-190.

LANDGRAF Ildikó: „Király, pásztor és nyáj egy legyen!” Az uralkodócsalád reprezentációja az 1867-1918 közötti magyar populáris olvasmányokban és hatásuk a szóbeli ha- gyományokra $=$ „A királyhüség jól bevált útján...”... 23-38. ill.

MonoK István: Similarities and Differences in the Book History of Central Eurpoe in the Early Moder Period. Aspects and Examples = Hungarian Studies (30.) 2016. 2. 137-153.

MoNoK István: Luther és Melanchthon műveinek előfordulási gyakorisága a kora újkori könyvjegyzékeken $=$ Mủvészet és mesterség. Tisztelgő kötet R. Várkonyi Ágnes emlékére / szerk. Horn Ildikó et al.. Bp.: L'Harmattan, 2016. 116-132.

Monok István: De la valeur documentaire des catalogues et des registres de livre - leur usage dans l'histoire de la réception $=\mathrm{Re}$ vista Transilvania (44.) 2016. 4-5. 172-176.

MoNOK István: Verbundkatalog der alten Drucke und Datenbank der aus dem Königreich Ungarn und Siebenbürgen stammenden Buchverzeichnisse. $1520-1800=$ Wolfenbütteler Notizen zur Buchgeschichte (40.) 2015. 133-141.

OláH Róbert: Két vers Helmeczi Komoróczi István Igasság paisához = Egyháztört. Szle (17.) 2016. 2. 114-117.

http://www.uni-miskolc.hu/ egyhtort/cikkek/oka-hki.pdf

OLÁH Róbert: Bibliák a kora újkori református lelkészi könyvtárakban $=$,Hiszek, hogy megértsem"! Doktoranduszok Országos Szövetsége Hittudományi Osztály Fiatal Kutatók és Doktoranduszok IV. Nemzetközi Teológuskonferenciája. Budapest, 2013. november 30. Konferenciakötet / szerk. GÉR András László, Jenei Péter, ZILA Gábor. Bp.: KREL'Harmattan, 2015. 334-340. (Károli könyvek. Tanulmánykötet)

A konferenciatanulmány bővített változata korábban megjelent: Egyháztört. Szle 2014/3. http://www.uni-miskolc.hu/ egyhtort/cikkek/ olahrobert-bibliak.pdf

OLÁH Róbert: Ortodoxia és okkultizmus? Nonkonformista müvek Miskolci Csulyak István és Tofeus Mihály könyvtárában = MKsz (132.) 2016. 1. 31-46.

OLÁH Róbert: Adalékok az „et amicorum” possessorbejegyzésekhez $=$ Monokgraphia... 521-526. 
OLÁH Róbert: A héber nyelv szerepe Tofeus Mihály műveltségében $=$ Studia. Debreceni teológiai tanulmányok (7.) 2016. 1. 51-62.

Ösz Sándor Előd: Kálvin János írásmagyarázati munkáinak 16. századi erdélyi olvasóiról = Hegyen épült város... 280-288.

Ösz Sándor Előd: Tordai Sándor András erdélyi református püspök két könyvéről $=$ In via eruditionis... 315-324.

Ősz Sándor Előd: A Vizsolyi Biblia eddig ismeretlen példánya a Kolozsvári Protestáns Teológiai Intézet könyvtárában $=$ Monokgraphia... 533-540.

Öтvös Péter: Szenci Molnár Albert német barátja, Martin Opitz Magyarországon $=\mathrm{In}$ via eruditionis ... 243-251.

Öтvös Péter: Opitz Márton olvas = Monokgraphia... 541-545.

PINTÉR Márta Zsuzsanna: Két pálos könyvjegyzék tanulságai $=$ Monokgraphia... 568573.

То́тн Zsombor: Cserei olvas.... Írásantropológiai és olvasástörténeti megfontolások az ifjú Cserei Mihály íráshasználati habitusában = Monokgraphia... 692-699. ill.

TüsKÉs Anna: The Library of Lawyer and Justice Minister Tivadar Pauler (1816-1886) in 1872 = Kniha (Martin, Slovenská Národná Kniznica) 2016. 265-275. ill.

VÁsÁRHELYI Judit, P: Johann Piscator autográf verse Hódmezővásárhelyen $=$ In via eruditionis...59-63. ill.

Adatok Johann Piscator magyarországi recepciójához.

VÁSÁRHELYI Judit, P.: Bibliaolvasó kalauz a 18. században = Monokgraphia... 721-725. ill.

VÉGHSEÖ Tamás:Bacsinszky András munkácsi püspök könyveinek jegyzéke 1790-bö1 = Monokgraphia... 726-744.

Bacsinszky András könyvjegyzékének közlésével

VERÓK Attila: Kriegsthematik in den Lesestoffen der Siebenbürger Sachsen. 16-18. Jahrhundert = Umwandlungen und Interferenzen. Studien aus dem Bereich der Germanistik. Beiträge der VI. Internationalen Germanistentagung an der Christlichen Universität Partium, Grosswardein. Nagyvárad =
Oradea, 18-19. September 2014 / hrsg. von Szabolcs JÁnos; Zsarb. mit Andrea BÁNFFIBenedek, Gizella Boszák. Wien: Praesens, 2016. 27-35.

\section{A múlt neves könyvtárosai, bibliográfusai, újságírói}

Arany Zsuzsanna: Kosztolányi Dezső élete. 1. rész. Forradalmak kora $=$ Alföld (67.) 2016. 6. 63-72.

Arany Zsuzsanna: Kosztolányi Dezső élete. 4. rész. Forradalmak kora=Alföld (67.) 2016. 10. 56-64.

Arany Zsuzsanna: Kosztolányi Dezső élete. 5. rész. Forradalmak kora =Alföld (67.) 2016. 11. 81-89.

BÉNYEI Miklós: Szabó Károly történetírói munkássága $=$ KKK (25.) 2016. 3. 33-40.

BoKa László: „A nekifeszült mentő akarat”. Kuncz és az Erdélyi Helikon = Honfoglaló, nagy írónemzedék. Az Erdélyi Helikon írói közösség megalakulásának 90. évfordulójáról megemlékező miskolci tudományos konferencia előadásai / szerk. KABÁN Annamária, Mózes Huba. Miskolc: Bíbor K., 2016. 43-50.

Borbás Andrea: De versek íródnak. Az Adyéletmü válaszai a ,mit tegyen az író a háborúval szemben" kérdésre = Propaganda. Politika, hétköznapi és magas kultúra, mủvészet és média a nagy háborúban... 325-335.

FüLEP Katalin: Berlász Jenő, 1911-2015 = KF (26.) 2016. 1. 70-75.

Függelékben Berlász Jenő önéletrajza 1945bö1. 1936 és 2000 között nyomtatásban megjelent munkáinak, tanulmányainak és cikkeinek bibliográfiája Buza János összeállításában és Rácz Ágnes „Berlász Jenő könyvtártörténeti tanulmányai az OSZK Híradó hasábjain" címü gyüjtése

GAAL György: Gál Kelemen, a szerkesztő = Certamen III. Előadások a Magyar Tudomány Napján az Erdélyi Múzeum-Egyesület I. szakosztályában. Nyelv-, irodalomnéprajztudomány történelem / szerk. EGYED 
Emese, PAKó László. Kolozsvár: Erdélyi Múzeum-Egyes., 2016. 141-149.

GrÁBERnÉ Bösze Klára: Rupp Kornél tanári pályája és a Tanulók Lapja létrehozása $=\mathrm{KN}$ (18.) 2016. 2. 35-49.

Horváth József: Az ifjú Gárdonyi és a „Garabonciás Diák" = Győri tanulmányok (37.) 2016. 41-52.

JuHÁsZ András: Vekerdi József. 1927-2015 = KKK (25.) 2016. 2. 40-46.

Kiszl Péter-Patkósné Tóth Zsuzsanna: „Szép szellemi szolgálat ez". Marót Miklós, 1928$2006=\mathrm{KF}$ (26.) 2016. 2. 231-244.

Lenyomat a FSZEK két évtizedéről (19481969) c. Marót Miklóssal készült interjú közlésével.

Kiszl Péter-Patкósné Tóth Zsuzsanna: Borsa Gedeon, az ízig-vérig bibliográfus $=\mathrm{KF}$ (26.) 2016. 3. 362-376.

A „Válassz olyan munkát, amit szeretsz, és soha többé nem kell dolgoznod!” címü Borsa Gedeonnal készült interjú közlésével.

Kiszl Péter-Patкósné Tóth Zsuzsanna: „A Széchényi Könyvtár nemcsak kenyeret adott nekem évtizedekig, de hivatást is". Kozocsa Sándor, 1904-1991 = KN (26.) 2016. 4. 512-522.

A „Készültem rá, hogy bibliográfus leszek, $\mathrm{s}$ az egész életemet ennek a szolgálatába fogom állítani” c. Kozocsa Sándorral készült interjú közlésével

KovÁcs I. Gábor: Az abaúji Szádeczky család első egyetemi tanár tagjának, Szádeczky-Kardoss Lajos történésznek az életútja $=$ Natio est semper reformanda ... 459-470.

LÁszló Bernát, V.: Keresztesharc a nyilaskereszt ellen. Bangha Béla nyilasellenes publicisz- tikája, 1936-1940 = Aetas (31.) 2016. 2. Törésvonalak. 121-132.

MÉszÁRos Tibor: „... az újságírás nem árt az írónak; kitűnő iskola és gyakorlat". A publicista Márai = Forrás (48.) 2016. 9. 62-96.

PogÁNy György: „Munkáját alaposság, lelkiismeretesség és széles látókör jellemzi”. Goriupp Alisz emlékezete $=\mathrm{KF}$ (26.) 2016. 1 . 51-58.

Az MKE Bibliográfiai Szekciója 2015. ápr. 24-i, a Budapesti Nemzetközi Könyvfesztiválon tartott rendezvényén elhangzott előadás szerkesztett változata

RÁcz Ágnes-Mezey László Miklós: Berlász Jenő: 1911-2015 = KKK (25.) 2016. 1. 49-50.

Rózsa Mária: Publikáló orvosok a Habsburgmonarchia német nyelvű sajtójában a hoszszú XIX. században = Alexander multifrons... 137-142.

RózsA Mária: Néhány adalék Ludassy (Gans) Móric bécsi hírlapírói tevékenységéhez. Die Debatte 1864-1869 MKsz (132.) 2016. 2. 210-214. ill.

SChMelczer-PohÁnKa Éva: Várkonyi Nándor emlékezete = KKK (25.) 2016. 11. 33-39.

То́тн Sándor László: Tömörkény István korai írói munkássága a Szegedi Híradóban, 1884-1888. = Tömörkény 150. Tanulmányok a 150 éve született Tömörkény István tiszteletére / szerk. Bene Zoltán. Szeged: Areión Kv., 2016. 135-181.

VesZTRÓcZy Zsolt: Kritikus vagy mameluk? A dualista kormányzat és a parlament müködése Mikszáth Kálmán parlamenti karcolatai alapján, 1881-1910 = Hatalmi diskurzusok... 159-168.

BORVÖLGYI GYÖRGYI 